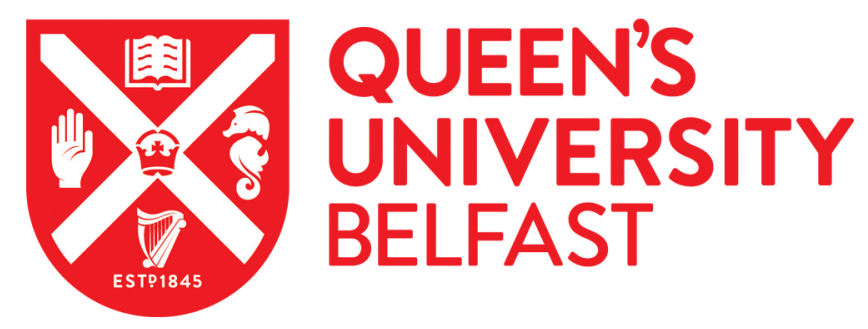

\title{
Production of sodium silicate powder from waste glass cullet for alkali activation of alternative binders
}

Vinai, R., \& Soutsos, M. (2019). Production of sodium silicate powder from waste glass cullet for alkali activation of alternative binders. Cement and Concrete Research, 116, 45-56.

https://doi.org/10.1016/j.cemconres.2018.11.008

\section{Published in:}

Cement and Concrete Research

\section{Document Version:}

Peer reviewed version

Queen's University Belfast - Research Portal:

Link to publication record in Queen's University Belfast Research Portal

\section{Publisher rights}

Copyright 2019 Elsevier Ltd.

This manuscript is distributed under a Creative Commons Attribution-NonCommercial-NoDerivs License

(https://creativecommons.org/licenses/by-nc-nd/4.0/), which permits distribution and reproduction for non-commercial purposes, provided the author and source are cited.

\section{General rights}

Copyright for the publications made accessible via the Queen's University Belfast Research Portal is retained by the author(s) and / or other copyright owners and it is a condition of accessing these publications that users recognise and abide by the legal requirements associated with these rights.

Take down policy

The Research Portal is Queen's institutional repository that provides access to Queen's research output. Every effort has been made to ensure that content in the Research Portal does not infringe any person's rights, or applicable UK laws. If you discover content in the Research Portal that you believe breaches copyright or violates any law, please contact openaccess@qub.ac.uk. 


\title{
Production of sodium silicate powder from waste glass cullet for alkali activation of alternative binders.
}

\author{
Raffaele Vinai*1,2 and Marios Soutsos ${ }^{1}$ \\ ${ }^{1}$ School of Natural and Built Environment, Queen's University Belfast, BT9 5AG United Kingdom \\ ${ }^{2}$ College of Engineering, Mathematics and Physical Sciences, University of Exeter, Harrison Building, EX4 \\ 4QF United Kingdom. \\ *Corresponding author: r.vinai@exeter.ac.uk, tel. +44 (0) 1392723627.
}

\section{Declarations of interest: none}

\begin{abstract}
A simple process to produce sodium silicate powder from glass cullet has been developed. A mixture of glass powder, sodium hydroxide powder, and water was heated at temperatures of 150 to $330{ }^{\circ} \mathrm{C}$. The effects of glass to $\mathrm{NaOH}$ ratio, temperature and duration, inclusion of water and fineness of $\mathrm{NaOH}$ were investigated. Fly ash and fly ash/GGBS blends were the precursors for alkali activated binder (AAB) mortars produced with this sodium silicate. Compressive strengths were similar to or better than those obtained with commercially available sodium silicate and sodium hydroxide solutions. FT-IR tests suggested that the reactivity of the glass derived sodium silicate powder was related to the number of non-bridging oxygen atoms in the silicate structure. Cost comparison between $\mathrm{AAB}$ and Portland cement concretes gave similar results for normal strength concretes (35 MPa). AAB concretes with higher strengths (50 and $70 \mathrm{MPa}$ ) can be cheaper than equivalent traditional concrete.
\end{abstract}

Keywords: alkali activated cement (D), glass (B), fly ash (D), granulated-blast furnace slag (D), waste-derived activator.

\section{Introduction}

Alkali activated binders (AAB) rely on the reaction of an aluminosilicate solid powder (called precursor) with an alkali metal (called activator). There is extensive literature on potential activators. The activator must be able to: (a) be efficient in triggering and ensuring the full reaction with the precursor in the desired time (too long reaction times might lead to low early age strength, whilst too short reaction times can result in fast setting problems); (b) 
be available at low cost and in sufficient quantity; (c) have a low environmental impact; (d) allow simple and costeffective use. Among all the available options for activators (hydroxides, silicates, sulfates, carbonates, acidic solutions), the use of alkali hydroxide (either sodium or potassium) combined with an alkali silicate (again either sodium or potassium) [1] is favoured as it has been shown to give high compressive strengths when used with fly ash and slag as precursors. However, the use of alkali hydroxide and silicate solutions has also disadvantages such as:

1. They are difficult to handle on site as they are highly alkaline liquid solutions, and this poses health and safety risks.

2. The costs, embodied energy and environmental impact associated with the production of the activators [26], especially those of the sodium silicate which is usually produced by melting sodium carbonate and silicon dioxide at a temperature of $1200-1400{ }^{\circ} \mathrm{C}$. This industrial process emits large quantities of $\mathrm{CO}_{2}$.

Other production methods are available, e.g. dissolution of quartz sand with sodium hydroxide in a reactor, but the energy requirements are again usually high [2,7-9]. The development of a solid activator, which can be premixed with a precursor and thus obtaining a "one-part" alkali activated binder where only water is required to be added to the mix, is highly desired by the industry [1]. A recently published review on one-part alkali-activated materials is available [10].

Anhydrous sodium silicate in powder form is available on the market but it needs pressure reactor vessels to get it properly dissolved. Hydrous powders in principle could be dissolved under normal atmospheric pressure conditions [11], but Rees et al. [12] found that the availability of free Si from solid powder was lower than from liquid silicates. The development of a powder (solid) activator is therefore a priority in the research agenda [1]. Attempts to find ways of reducing the cost and environmental impact of activators have mainly focused on hydrothermal processes to produce silicate solutions from by-products such as condensed silica fume [13-14] and rice husk ash [15-18]. These have the potential of reducing the global warming potential of AAB concretes by more than $70 \%$ compared to Portland cement-based concrete [19]. However, the cost of AAB concretes is not significantly reduced and this remains higher than Portland cement based concretes.

Waste glass cullet has also been identified as a potential source of silicate, this being $70-75 \%$ of amorphous silica. Glass cullet can be used for the production of new glass but colour, composition, and contamination reduce the amount that can be reused. The percentage of glass rejected by the so-called "closed loop" due to impurities has been estimated to be between $6 \%$ and $15 \%$ in Italy [20]. A study carried out in 2003 indicated that, if UK would meet the recycling target of $60 \%$ and under the hypothesis of consuming the recycled glass nationally (i.e. 
without shipping the excess glass cullet abroad), 400,000 tonnes of glass cullet would still be available for other uses than production of glass containers [21]. This recycling target of $60 \%$ was achieved and even exceeded in recent years [22], thus, the availability of glass cullet in UK is significant. Even the process of recycling of glass produces a waste stream which is a very fine powder that is collected by dust extraction units. Due to its chemistry and its availability, waste glass is therefore a good candidate for the production of AAB. Some recent studies describe its utilisation as total or partial replacement of usual precursors, suggesting that satisfactory strength can be achieved by activation of $100 \%$ waste glass fibres with $\mathrm{NaOH}$ only [23] or by substituting up to $60 \%$ of fly ash in blended fly ash-ground granulated blast furnace slag (GGBS) system [24].

Focussing on the use of waste glass for the production of low cost, environmentally friendly silicate solution, some patents [25-27] and production methods exist:

- Hydrothermal methods involve heating of the glass in an alkaline solution. Factors influencing the dissolution rate were (a) temperature, (b) glass composition, (c) particle size and (d) type of alkaline cation ( $\mathrm{Na}$ or $\mathrm{K}$ ) in the solution [28-31]. Attempts to increase the dissolution focussed on increasing the temperature to between 150 and $250{ }^{\circ} \mathrm{C}$ which required pressure reactor vessels as the self-generated pressure was up to $30 \mathrm{~atm}$. The silica dissolution was about 72\% [32]. There are however concerns with regards to the corrosive nature of the solutions that can damage the pressure reactor vessels. Temperatures less than $100{ }^{\circ} \mathrm{C}$ proved that the process works [33 - 38], but the dissolution rate was low, e.g., $26 \%$ of $\mathrm{SiO}_{2}$ from the $70 \%$ in the glass. Although these were used successfully for slag activation $[33,37-38]$ their molarity was low compared to commercial solutions and thus the maximum potential strength of the precursor could not be achieved. A literature analysis of hydrothermal methods for the extraction of silicate from waste in aqueous alkali solutions was detailed in a previous study [18].

- Thermochemical or fusion methods involve mixing glass and $\mathrm{NaOH}$ powders and heating the mixture to very high temperature, e.g., $500^{\circ} \mathrm{C}[39], 650{ }^{\circ} \mathrm{C}$ [40], and 700 to $1300{ }^{\circ} \mathrm{C}$ [41]. Conversion of glass to sodium silicate was high but the solubility of the produced powder at ambient pressure was low thus requiring reheating at $175{ }^{\circ} \mathrm{C}$ for at least one hour and still not fully dissolving. The procedure for obtaining pure sodium silicate from sand is considered "simple" chemistry and involves mixing sand with sodium hydroxide in a 2:1 mass ratio and heating to $320^{\circ} \mathrm{C}$ for at least 10 minutes, although one hour is recommended. The melting point of the $\mathrm{NaOH}$ is about $318{ }^{\circ} \mathrm{C}$ and the following chemical reaction is produced:

$2 \mathrm{NaOH}+\mathrm{SiO}_{2} \rightarrow \mathrm{Na}_{2} \mathrm{SiO}_{3}+\mathrm{H}_{2} \mathrm{O}$ 
This procedure has the advantage that:

(a) It produces a powder rather than a solution. This makes a one-part alkali activated binder system possible.

(b) It reduces significantly the cost for the production of the activator and thus subsequently reducing the cost of alkali activated concretes.

(c) It has a lower carbon footprint as it uses low temperature process.

The research aimed at adapting the above procedure so that ground glass cullet could be used with the aim of lowering even further the required temperature for the process enabling the use of ordinary laboratory ovens. The work was carried out in four phases:

1. Assessment of the effect of variables such as (a) the $\mathrm{SiO}_{2}: \mathrm{Na}_{2} \mathrm{O}$ ratio, (b) the inclusion of water, (c) the temperature and the duration of the process, (d) the fineness of $\mathrm{NaOH}$ on the chemical composition of the sodium silicate powder.

2. Determination of the efficiency of the sodium silicate powder when used as an activator for AAB. Comparison of compressive strength of mortars produced using (a) glass-derived sodium silicate powder and (b) commercially available sodium silicate solution.

3. Microstructural investigation of the physico-chemical properties of the produced powder in order to understand its reactivity potential.

4. A cost analysis for concretes to assess the economic benefits arising from the use of the glass-derived sodium silicate powder. Comparison of AAB concretes thus produced with those with commercially available sodium silicate solution and also Portland cement based ones.

\section{Materials and experimental methods}

Glass cullet was sourced from a local recycler in Northern Ireland and had glass chips of different colours and sizes as it was from domestic glass containers (bottles). It was milled by means of a Retsch PM400 Ball Mill, capable of grinding around $440 \mathrm{~g}$ of glass $(110 \mathrm{~g}$ in each of the four $500 \mathrm{ml}$ hardened steel grinding jars, each loaded with ten hardened steel grinding balls, $15 \mathrm{~mm}$ diameter) at a speed of $300 \mathrm{rpm}$. Grain size distribution was obtained by means of laser diffraction particle size analyser (Malvern Panalytical Mastersizer 2000). The $\mathrm{D}_{50}$ value (i.e. the value of the particle size at $50 \%$ in the cumulative distribution) showed that the milling time improved the fineness of the material. The $\mathrm{D}_{50}$ reduced from around $17 \mu \mathrm{m}$ (milling for 5 minutes) to about 12 $\mu \mathrm{m}$ when the material was milled for 10 minutes, see Figure 1 . Grinding the material for 10 minutes at $300 \mathrm{rpm}$ was considered suitable and adopted in this study. The oxide composition of the glass powder was obtained from $\mathrm{X}$-ray fluorescence (XRF) and it is shown in Table 1. Whilst XRF results can be considered satisfactory reference 
values, traces of other elements, such as $\mathrm{Cr}$ and $\mathrm{Ba}$, which are frequently found in glass, might have not been detected. Analysis of trace elements with other techniques such as laser-induced breakdown spectroscopy [42] would give further insight on the chemistry of the glass, but this was not possible to be done for this work.

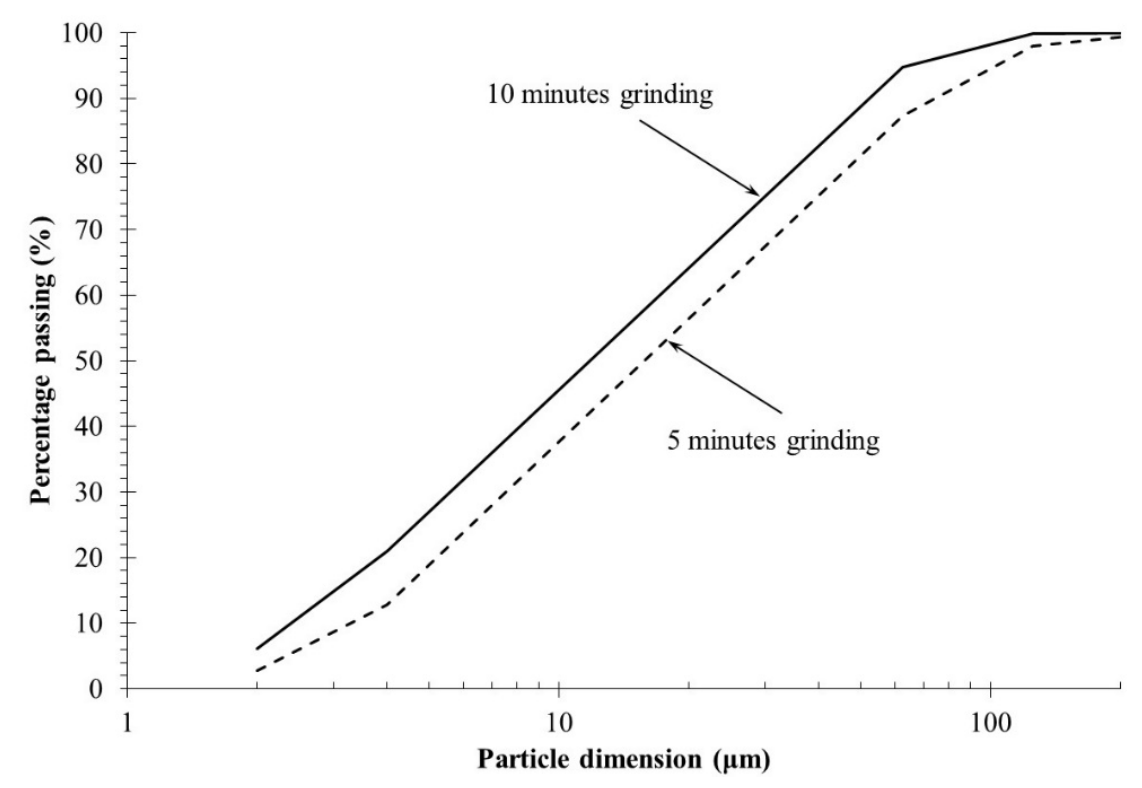

Fig. 1. Particle size distribution of used glass powder.

Table 1. Oxide composition (in mass \%) of the glass powder, fly ash and GGBS used in the study.

\begin{tabular}{ccccccccccccc}
\hline Element & $\mathrm{SiO}_{2}$ & $\mathrm{TiO}_{2}$ & $\mathrm{Al}_{2} \mathrm{O}_{3}$ & $\mathrm{Fe}_{2} \mathrm{O}_{3}$ & $\mathrm{MnO}$ & $\mathrm{MgO}$ & $\mathrm{CaO}$ & $\mathrm{Na}_{2} \mathrm{O}$ & $\mathrm{K}_{2} \mathrm{O}$ & $\mathrm{P}_{2} \mathrm{O}_{5}$ & $\mathrm{SO}_{3}$ & $\mathrm{LOI}$ \\
\hline Glass & 71.51 & 0.07 & 1.74 & 0.34 & 0.028 & 1.34 & 10.73 & 13.29 & 0.64 & 0.01 & 0.089 & 0.27 \\
\hline Fly ash & 46.78 & 1.05 & 22.52 & 9.15 & 0.05 & 1.33 & 2.24 & 0.89 & 4.09 & 0.17 & 0.90 & 3.57 \\
\hline GGBS & 36.5 & 0.5 & 10.4 & 0.7 & 0.4 & 8.1 & 42.4 & 0.5 & 0.2 & 0.00 & 0.3 & - \\
\hline
\end{tabular}

Commercial grade sodium hydroxide (Atznatron caustic soda from AkzoNobel, Germany) in microprills was used for the reaction with the ground glass cullet.

An electric furnace (Carbolite RHF 1600, UK) was used for heating samples and preparing powders for X-ray diffraction tests and for Fourier Tranform Infrared spectroscopy (FTIR) tests. Powders for mortar tests were produced either with a SNOL $39 / 1100$ electric furnace (UK) at $330{ }^{\circ} \mathrm{C}$ process temperature or with conventional laboratory ovens for lower temperatures.

X-ray diffraction (XRD) tests were carried out with a PANalytical X'Pert PRO diffractometer using pure Cu K $\alpha$ 1 radiation with wavelength $1.54 \AA$. The $\mathrm{X}$-ray generator was set to $40 \mathrm{kV}$ and $40 \mathrm{~mA}$, the recorded angular range was 5 to 65 or $70^{\circ}(2 \theta)$ with a step close to $0.017^{\circ}$. PANalytical X'Pert Highscore software was used for data interpretation and Rietveld analysis. 
FT-IR was carried out using a Jasco 4100 series FTIR Spectrometer with Attenuated Total Reflectance attachment (germanium crystal), recording data in transmittance mode over the range 650 to $4000 \mathrm{~cm}^{-1}$, with a data interval $0.964 \mathrm{~cm}^{-1}$. Jasco software was used for data interpretation.

Mortars were prepared by mixing the required amounts of binder, activator and sand in a 51 planetary mixer. A sand:binder ratio of 2.75 was used. Binders consisted either of a blend of fly ash and ground granulated blast furnace slag (GGBS) or neat fly ash. Fly ash was sourced from a power plant in England (Drax Power Station), whilst GGBS was supplied by Ecocem (Ireland). Chemical composition of fly ash was obtained with XRF analysis, whilst chemical composition of GGBS was provided by the producer. Oxide compositions are shown in Table 1. The powder developed in the study was used for activating the binders for mortars. Control mortar mixes were produced using commercially available sodium silicate solution (Fisher Scientific with $\mathrm{SiO}_{2}$ content equal to $25.5 \%$ and $\mathrm{Na}_{2} \mathrm{O}$ content of $12.8 \%$, i.e. $\mathrm{SiO}_{2} / \mathrm{Na}_{2} \mathrm{O}=2$ ) and a sodium hydroxide solution prepared by dissolving the Atznatron caustic soda in water at 30\% mass concentration. Natural sand with grain size distribution from 0 to $4 \mathrm{~mm}$ was used. Two $50 \mathrm{~mm}$ cubes for each mix were tested at 1, 7 and 28 days for compressive strength. Cubes were kept wrapped in cling film for the first 24 hours after which they were unwrapped and left to air cure. Samples produced with fly ash/GGBS blends were cured at room temperature, whilst samples with neat fly ash were cured in an oven at $70{ }^{\circ} \mathrm{C}$ until testing.

\section{Results and discussion}

\subsection{Optimisation of thermochemical process for the production of sodium silicate powder}

A preliminary trial was carried out aiming to reproduce the conditions necessary for the reaction described in Eq. (1) to develop. A dry mix of $\mathrm{NaOH}$ and glass powder was prepared with $\mathrm{SiO}_{2}: \mathrm{Na}_{2} \mathrm{O}$ mass ratio equal to 1 and processed in a furnace at a temperature of $330^{\circ} \mathrm{C}$ (i.e. slightly over the $\mathrm{NaOH}$ melting temperature) for two hours (labelled 1-330-2). The various steps in the procedure are shown in Figure 2.

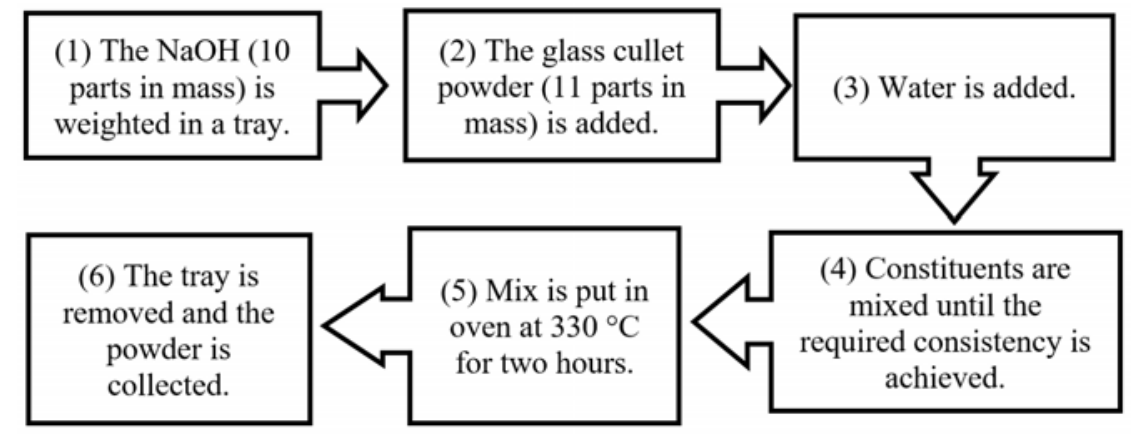

Fig. 2. Procedure steps for the production of the activating powder. 
XRD analysis on the produced activating powder, see Figure 3, showed that the thermochemical process transformed the material from a fully amorphous (diffraction pattern with a broad hump and no peaks) to a crystalline powder with a number of peaks identified as sodium silicates with different $\mathrm{SiO}_{2}: \mathrm{Na}_{2} \mathrm{O}$ ratios, calcium aluminium oxide and sodium carbonate. The main mineral phase was $\mathrm{Na}_{2} \mathrm{SiO}_{3}$ and this indicated that the procedure was successful.

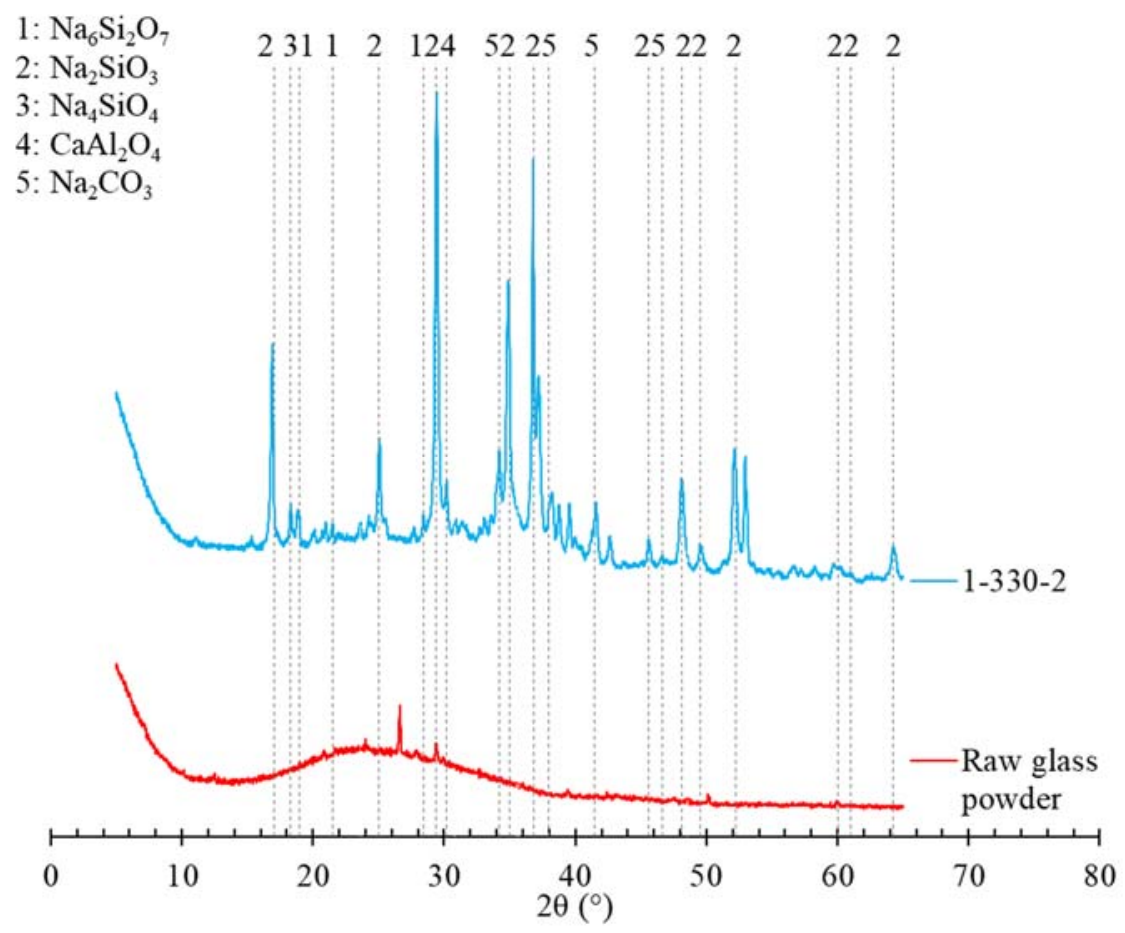

Fig. 3. XRD patterns of the processed powder activator compared to the raw glass powder.

A number of parameters were therefore subsequently investigated for optimising the sodium silicate production process (minimising the unreacted glass powder): (1) the $\mathrm{SiO}_{2}: \mathrm{Na}_{2} \mathrm{O}$ ratio (varied from $4: 1$ to $1: 1$ ), (2) the presence of water in the initial mix, (3) the process temperature, $150,250,330$ and $450{ }^{\circ} \mathrm{C}$, (4) the process duration, 1, 2 and 4 hours, and the fineness of $\mathrm{NaOH}$, i.e. prill or ground. The various samples investigated are shown in Table 2. Labels indicate the $\mathrm{SiO}_{2}: \mathrm{Na}_{2} \mathrm{O}$ ratio followed by the process temperature, duration and whether the sample was wet or dry, and whether the $\mathrm{NaOH}$ was ground or not.

The $\mathrm{SiO}_{2}: \mathrm{Na}_{2} \mathrm{O}$ molar ratio was calculated assuming that the $\mathrm{SiO}_{2}$ content in the glass was equal to $70 \%$ (see Table 1) and considering that the $\mathrm{Na}_{2} \mathrm{O}$ content in $\mathrm{NaOH}$ is $77.5 \%$. 
Processed activator powders were analysed with XRD in order to assess the nature and estimate the quantity of obtained silicates, as well as the degree of reaction. The presence of a hump is an indicator of the presence of amorphous material in the powder (and therefore presence of unreacted glass), whilst a nearly flat baseline suggests almost fully crystalline structures (and therefore full or almost full reaction, although some reaction products might be amorphous as well).

Table 2. Parameters investigated for the thermochemical process assessment.

\begin{tabular}{cccccc}
\hline $\begin{array}{c}\text { Sample } \\
\text { label }\end{array}$ & $\begin{array}{c}\mathbf{S i O}_{2}: \mathbf{N a}_{2} \mathbf{O} \\
(\mathbf{m o l})\end{array}$ & $\begin{array}{c}\text { Water included } \\
(\text { yes/no) }\end{array}$ & $\begin{array}{c}\text { Process } \\
\text { temp. }\left({ }^{\circ} \mathbf{C}\right)\end{array}$ & $\begin{array}{c}\text { Process } \\
\text { time (h) }\end{array}$ & $\begin{array}{c}\text { NaOH fineness } \\
\text { (prills, ground) }\end{array}$ \\
\hline $4-330-2$ & $4: 1$ & No & 330 & 2 & Prills \\
$2-330-2$ & $2: 1$ & No & 330 & 2 & Prills \\
$1-330-2$ & $1: 1$ & No & 330 & 2 & Prills \\
$2-330-2 \mathrm{w}$ & $2: 1$ & Yes & 330 & 2 & Prills \\
$1-330-1 \mathrm{w}$ & $1: 1$ & Yes & 330 & 1 & Prills \\
$1-330-2 \mathrm{w}$ & $1: 1$ & Yes & 330 & 2 & Prills \\
$1-150-2 \mathrm{w}$ & $1: 1$ & Yes & 150 & 2 & Prills \\
$1-250-2 \mathrm{w}$ & $1: 1$ & Yes & 250 & 2 & Prills \\
$2-450-2$ & $2: 1$ & No & 450 & 2 & Prills \\
$1-330-1$ & $1: 1$ & No & 330 & 1 & Prills \\
$2-330-4$ & $2: 1$ & No & 330 & 4 & Prills \\
$2-330-2 \mathrm{f}$ & $2: 1$ & No & 330 & 2 & Ground \\
\hline
\end{tabular}

The estimation of the amorphous content of the powders was carried out according to the method described by Tiainen et al. [43], which uses the area under the halo in a XRD pattern for semi-quantitative determination of the amorphous content. The method involves the following steps:

- Calculation of the integrated area under the baseline of the XRD pattern $\left(A_{b}\right)$ in the range $10^{\circ}$ to $70^{\circ}(2 \theta)$.

- Calculation of the total integrated area under the XRD pattern $\left(A_{t}\right)$ in the range $10^{\circ}$ to $70^{\circ}(2 \theta)$.

- $\quad$ Calculation of the ratio $R_{a}=A_{b} / A_{t}$

A linear correlation exists between the ratio $R_{a}$ and the amorphous content of the powder. Tiainen et al. suggested that a calibration curve should be built using known amount of amorphous contents in the investigated matrix. However, in their study it was found that significant variation in the matrix composition did not result in major differences in the calibrating curve [43]. For this investigation, the $R_{a}$ calculated for raw glass was used as calibration point for $100 \%$ amorphous content, whilst the mix $1-150-2 \mathrm{w}$, being the mix resulting in the flattest baseline (determined as deviation from the horizontal line), was used as second calibration point, estimated from [43] at about $30 \%$ amorphous content. A sensitivity analysis carried out by varying the assumed amorphous 
content of the second calibration point by $\pm 10 \%$ suggested that variations were limited and acceptable under the assumptions made. Results from this exercise are shown in Table 3.

Table 3. Estimation of the amorphous content of investigated samples.

\begin{tabular}{ccc}
\hline Sample label & $\boldsymbol{R}_{\boldsymbol{a}}(\mathbf{\%})$ & $\begin{array}{c}\text { Estimated amorphous } \\
\text { content (\%) }\end{array}$ \\
\hline Raw glass & 93.8 & 100 \\
$4-330-2$ & 88.9 & 90 \\
$2-330-2$ & 80.8 & 70 \\
$1-330-2$ & 76.0 & 60 \\
$2-330-2 \mathrm{w}$ & 75.0 & 60 \\
$1-330-1 \mathrm{w}$ & 64.2 & 35 \\
$1-330-2 \mathrm{w}$ & 66.2 & 40 \\
$1-150-2 \mathrm{w}$ & 61.8 & 30 \\
$1-250-2 \mathrm{w}$ & 64.9 & 35 \\
$2-450-2$ & 83.4 & 75 \\
$1-330-1$ & 75.2 & 60 \\
$2-330-4$ & 84.6 & 80 \\
$2-330-2 \mathrm{f}$ & 82.1 & 75 \\
\hline
\end{tabular}

The identification of mineral phases was carried out using X'Pert software, which was also used for the Rietveld analysis for the quantification of the mineral phases. Obtained results were then corrected according to the estimation of the amorphous content, and quantities of mineral compounds were therefore assessed. Due to the semi-quantitative nature of the adopted approach, results are only precise to $+/-10 \%$. Result are shown in Table 4.

Table 4. Mineral composition from Rietveld analysis on processed powder activator.

\begin{tabular}{|c|c|c|c|c|c|c|c|c|c|c|c|c|}
\hline Mineral & 4-330-2 & $2-330-2$ & $1-330-2$ & $2-330-2 w$ & $1-330-1 w$ & $1-330-2 w$ & $1-150-2 w$ & $1-250-2 w$ & $2-450-2$ & $1-330-1$ & $2-330-4$ & $2-330-2 f$ \\
\hline $\mathrm{Na}_{2} \mathrm{SiO}_{3}$ & $5 \%$ & $20 \%$ & $24 \%$ & $36 \%$ & $63 \%$ & $54 \%$ & $67 \%$ & $61 \%$ & $7 \%$ & $29 \%$ & $11 \%$ & $18 \%$ \\
\hline $\mathrm{Na}_{4} \mathrm{SiO}_{4}$ & $1 \%$ & $0 \%$ & $3 \%$ & $0 \%$ & $1 \%$ & $0 \%$ & $0 \%$ & $0 \%$ & $3 \%$ & $0 \%$ & $1 \%$ & $2 \%$ \\
\hline $\mathrm{Na}_{6} \mathrm{Si}_{2} \mathrm{O}_{7}$ & $0 \%$ & $1 \%$ & $4 \%$ & $0 \%$ & $0 \%$ & $0 \%$ & $0 \%$ & $0 \%$ & $11 \%$ & $0 \%$ & $1 \%$ & $0 \%$ \\
\hline $\mathrm{Na}_{2} \mathrm{CO}_{3}$ & $2 \%$ & $8 \%$ & $9 \%$ & $3 \%$ & $0 \%$ & $6 \%$ & $0 \%$ & $0 \%$ & $2 \%$ & $10 \%$ & $6 \%$ & $4 \%$ \\
\hline $\mathrm{CaAl}_{2} \mathrm{O}_{4}$ & $1 \%$ & $1 \%$ & $1 \%$ & $1 \%$ & $1 \%$ & $0 \%$ & $3 \%$ & $2 \%$ & $0 \%$ & $1 \%$ & $1 \%$ & $1 \%$ \\
\hline $\mathrm{Na}_{2} \mathrm{CaSiO}_{4}$ & $0 \%$ & $0 \%$ & $0 \%$ & $0 \%$ & $0 \%$ & $0 \%$ & $0 \%$ & $2 \%$ & $2 \%$ & $0 \%$ & $0 \%$ & $0 \%$ \\
\hline Amorphous & $90 \%$ & $70 \%$ & $60 \%$ & $60 \%$ & $35 \%$ & $40 \%$ & $30 \%$ & $35 \%$ & $75 \%$ & $60 \%$ & $80 \%$ & $75 \%$ \\
\hline
\end{tabular}

Two main factors were found to be key parameters for improving the efficiency of the reaction (i.e. maximising the crystalline content of the powder): (a) the amount and availability of $\mathrm{Na}_{2} \mathrm{O}$ (from $\mathrm{NaOH}$ ) and (b) the addition 
of water in the blend before heating. Samples with $\mathrm{SiO}_{2}: \mathrm{Na}_{2} \mathrm{O}$ ratio equal to 1 had the lowest amorphous content, indicating high degree of reaction, see Figure 4. Attempts to obtain sodium silicate with a higher silica ratio, by using high amounts of glass powder, resulted in only partial reaction, e.g. sample 4-330-2 (with $\mathrm{SiO}_{2}: \mathrm{Na}_{2} \mathrm{O}$ ratio equal to 4) had a very high amorphous content whilst samples with $\mathrm{SiO}_{2}: \mathrm{Na}_{2} \mathrm{O}$ ratios of 2 had intermediate amorphous contents.

XRD patterns indicated that the processed activating powder had higher crystalline content when a small amount of water was added to the $\mathrm{NaOH} /$ glass powder blend to produce a paste before it was heated. The presence of water in sample 2-330-2w resulted in the highest reflection peaks for $\mathrm{Na}_{2} \mathrm{SiO}_{3}$, although certain amorphous fraction was still observed. Samples 1-330-1w and 1-330-2w, which combined the best $\mathrm{SiO}_{2}: \mathrm{Na}_{2} \mathrm{O}$ ratio with the improved mixing procedure, resulted in reacted powder with very high content of sodium silicates, mainly in the form of $\mathrm{Na}_{2} \mathrm{SiO}_{3}$, see Figure 5. It appears that water addition led to the partial dissolution of $\mathrm{NaOH}$ which then, after water evaporation due to the heating, precipitated as a thin layer around the glass powder grains. The micro (or nano) scale of the deposited $\mathrm{NaOH}$ layer, and thus its improved contact with glass powder grains, might have resulted in an improved reaction.



Fig. 4. XRD patterns of the processed activating powders - effect of $\mathrm{SiO}_{2}: \mathrm{Na}_{2} \mathrm{O}$ ratio. 


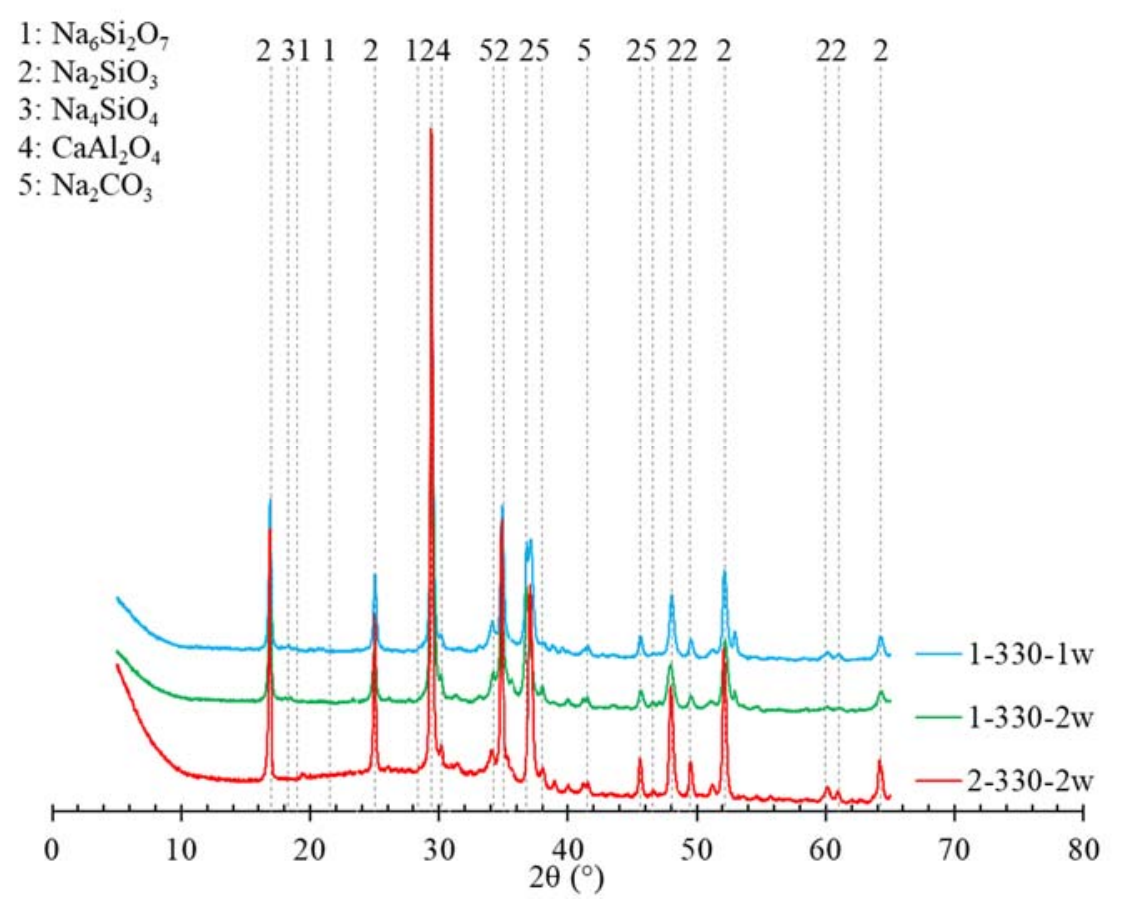

Fig. 5. XRD patterns of the processed activating powders - effect of water content.

Higher process temperature resulted in more complex sodium silicate forms, with increased presence of Na-rich silicates such as $\mathrm{Na}_{4} \mathrm{SiO}_{4}$ (i.e. $2 \mathrm{Na}_{2} \mathrm{O} \cdot \mathrm{SiO}_{2}$ ) and $\mathrm{Na}_{6} \mathrm{Si}_{2} \mathrm{O}_{7}\left(\right.$ i.e. $3 \mathrm{Na}_{2} \mathrm{O} \cdot 2 \mathrm{SiO}_{2}$ ). Sample 2-450-2 (heated at $450{ }^{\circ} \mathrm{C}$ ) was mainly $\mathrm{Na}_{6} \mathrm{Si}_{2} \mathrm{O}_{7}$, but with small quantities of $\mathrm{Na}_{2} \mathrm{SiO}_{3}, \mathrm{Na}_{4} \mathrm{SiO}_{4}$, and sodium calcium silicate $\left(\mathrm{Na}_{2} \mathrm{CaSiO}_{4}\right)$. Sample 2-330-2 (heated at $330^{\circ} \mathrm{C}$ ) was mainly $\mathrm{Na}_{2} \mathrm{SiO}_{3}$. Phase diagrams for $\mathrm{Na}_{2} \mathrm{O}-\mathrm{SiO}_{2}$ systems $[44,45]$ suggest that a temperature above $700{ }^{\circ} \mathrm{C}$ is needed, with an excess of $\mathrm{SiO}_{2}$ (about $70 \%$ ) in the mix in order to obtain sodium silicates with high $\mathrm{SiO}_{2}$ content, e.g., $\mathrm{Na}_{6} \mathrm{Si}_{8} \mathrm{O}_{19}\left(3 \mathrm{Na}_{2} \mathrm{O} \cdot 8 \mathrm{SiO}_{2}\right)$.

Surprisingly, when the temperature used was below $330{ }^{\circ} \mathrm{C}$, i.e. at $150{ }^{\circ} \mathrm{C}$ and $250{ }^{\circ} \mathrm{C}$, obtained XRD patterns were very similar to the ones obtained at $330^{\circ} \mathrm{C}$, see Figure 6 . A possible explanation for this is that the $\mathrm{NaOH}$ deposited on the glass powder grains after evaporation of water (as previously described) was at a nano-size scale (as the $\mathrm{NaOH}$ was initially dissolved), and the $\mathrm{NaOH}$ melting point was consequently suppressed (due to the size of the deposited particles) [46]. 


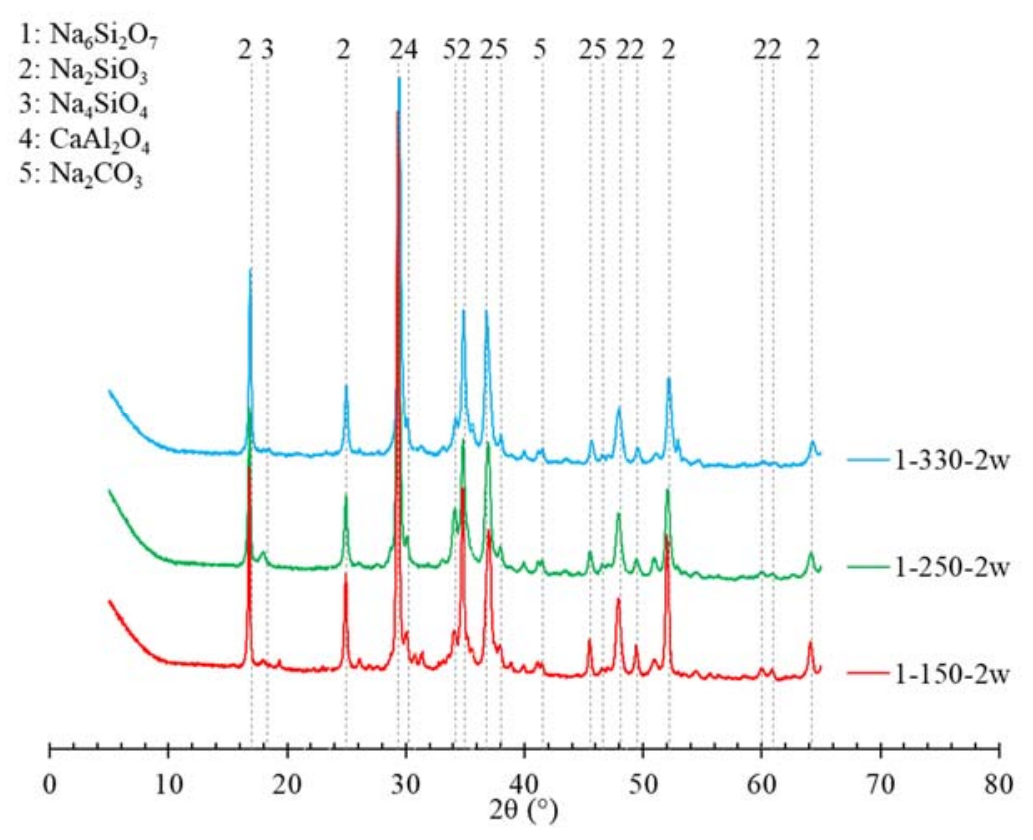

Fig. 6. XRD patterns of the processed activating powders - effect of heating temperature.

No significant difference was observed among XRD patterns of mixes with the same composition and temperature but different heating duration, i.e. 1, 2 and 4 hours (i.e. comparing 1-330-2 with 1-330-1, 2-330-2 with 2-330-4, and 1-330-2w with 1-330-1w). Therefore, duration of one hour for heating seems to be sufficient.

Only a marginal increase of $\mathrm{Na}_{2} \mathrm{SiO}_{3}$ was observed when the $\mathrm{NaOH}$ was ground. There was also some minor presence of $\mathrm{Na}_{4} \mathrm{SiO}_{4}$ in sample 2-330-2f when compared to sample 2-330-2.

The above discussed results indicate that the most important process parameters to achieve the optimum reaction (i.e. processed activating powder composed of crystalline sodium silicates) were: (a) the availability of enough $\mathrm{NaOH}$ for achieving a theoretical $\mathrm{SiO}_{2}: \mathrm{Na}_{2} \mathrm{O}$ molar ratio equal to 1 , i.e. a glass powder : $\mathrm{NaOH}$ mass ratio equal to $11: 10$, (b) converting the powder into paste by adding water before heating, and (c) heating for 1 hour at a temperature between $150{ }^{\circ} \mathrm{C}$ and $330{ }^{\circ} \mathrm{C}$. These optimum process parameters were therefore used for producing the activation powder used for the subsequent work.

\subsection{Efficiency of the developed powder activator}

In order to determine the efficiency of the powder activator, the compressive strengths of AAB mortars with the developed powder activator were compared to those with commercially available sodium hydroxide and sodium silicate. 
The developed sodium silicate powder was used for activating the binder. The amount of powder activator needed for the mortar mixes was determined based on the required alkali dosage $(M+)$ and alkali modulus $(A M)$. $M+$ is the percentage mass ratio $\mathrm{Na}_{2} \mathrm{O}$ /binder, and $\mathrm{AM}$ is the mass ratio $\mathrm{Na}_{2} \mathrm{O} / \mathrm{SiO}_{2}$. In the literature, silica modulus (SM) is often used, i.e. the ratio $\mathrm{SiO}_{2} / \mathrm{Na}_{2} \mathrm{O}$, which corresponds to $1 / \mathrm{AM}$. The required $\mathrm{SiO}_{2}$ mass was calculated based on the $\mathrm{SiO}_{2}$ mass content in $\mathrm{Na}_{2} \mathrm{SiO}_{3}$. AM higher than 1 (i.e. $\mathrm{SM}<1$ ) required not only the powder activator but also extra $\mathrm{Na}_{2} \mathrm{O}$, i.e., the $\mathrm{Na}_{2} \mathrm{O}$ exceeding the quantity available from the dissolution of the sodium metasilicate, and this was provided by adding $\mathrm{NaOH}$ solution (30\% mass concentration).

The powder activator was dissolved in the required water volume (i.e. mass of water required for desired water to solid ratio (w/s), minus the water included in the $\mathrm{NaOH}$ solution) just before mixing.

According to the semi-quantitative determination of the chemical composition of powder shown in Table 4, the activators produced with the optimised process (i.e., samples with $\mathrm{SiO}_{2}: \mathrm{Na}_{2} \mathrm{O}$ ratio equal to 1 heated for 1 hour at a temperature between $150{ }^{\circ} \mathrm{C}$ and $330{ }^{\circ} \mathrm{C}$ ) had about $65 \%$ in mass of silicates. However, the variability associated with the determination of the amorphous content as well as the possible presence of reacting silicates in amorphous form could lead to underestimate the actual amount of silicates. For this reason, a less conservative value of $80 \%$ was also investigated. An "efficiency factor" (EF) defined as the ratio between the available $\mathrm{SiO}_{2}$ and the mass of the powder activator ranging from $65 \%$ to $80 \%$ was assumed and tried in four series of mortars with sand-to-binder ratio $=2.75$. Mixes were labelled with the following sequence: fly ash content $-\mathrm{AM}-\mathrm{EF}-$ powder production temperature. When the powder was added in solid form in the mix, the letter "s" was added after the EF value.

1. Series I - Mixes 60-1.25-65-330 and 60-1.25-80-330 had 60\%/40\% fly ash/GGBS binder blend with activator dosages $\mathrm{M}+=7.5 \%$ and $\mathrm{AM}=1.25$ (i.e. $\mathrm{SM}=0.8$ ) and activating powder produced at $330{ }^{\circ} \mathrm{C}$. The aim of this series was to compare strengths at $\mathrm{AM}=1.25$ which has previously been shown to result in the highest possible compressive strength [47]. As such, sodium hydroxide solution in addition to the activating powder was required for achieving $\mathrm{AM}=1.25$. Efficiency factors of $65 \%$ and $80 \%$ were investigated.

2. Series II - Mixes 60-1.0-80-330, 60-1.0-65-330 and 60-1.0-65s-330 had 60\%/40\% fly ash/GGBS binder blend with activator dosages $\mathrm{M}+=7.5 \%$ and $\mathrm{AM}=1.0$ (i.e. $\mathrm{Na}_{2} \mathrm{O} / \mathrm{SiO}_{2}=1$, corresponding to $\mathrm{SM}=1$ ). The aim was to use only activating powder without additional sodium hydroxide solution. Mix 60-1.065-330 was repeated by adding the dry powder directly in the mixer with fly ash and GGBS, and then adding the required water (mix $60-1.0-65 \mathrm{~s}-330$ ). 
3. Series III - Mixes 100-1.0-65-330 and 100-1.0-80-330 were with neat fly ash, $\mathrm{M}+=7.5 \%$ and $\mathrm{AM}=1.0$ (i.e. $\mathrm{SM}=1$ ). The aim was to investigate the efficiency of the activating powder on neat fly ash mixes.

4. Series IV - Mixes 60-1.0-65-150 and 100-1.0-65-150 were aimed at assessing the efficiency of activation powder produced at $150{ }^{\circ} \mathrm{C}$ instead of $330{ }^{\circ} \mathrm{C}$. Both fly ash/GGBS blend and neat fly ash mixes were investigated.

Series I: $60 \% / 40 \%$ fly ash/GGBS mixes with $A M=1.25$. Series I aimed at assessing the efficiency factor (EF) of the activating powder at an $\mathrm{AM}=1.25(\mathrm{SM}=0.8)$ with $60 \% / 40 \%$ fly ash/GGBS blends. Table 5 shows the mortar proportions and Figure 7 shows the obtained compressive strengths at 1, 7 and 28 days. The compressive strengths of the powder activator at 1-day were much lower than those with the commercial solution. However, the average compressive strength at 28-days improved considerably and they were comparable with the strength obtained with the commercially available solution. This indicated that the powder activator was participating in the reaction (higher strengths than $\mathrm{NaOH}$ only activated mortars) but perhaps its dissolution was slow and thus contributed to strength more at 28-days rather than early ages, i.e. 1- and 7-days. The additional $\mathrm{NaOH}$ added to these mixes to obtain an $\mathrm{AM}=1.25(\mathrm{SM}=0.8)$ was suspected of interacting with the activator powder. The next series of mixes therefore investigated an $\mathrm{AM}=1.0(\mathrm{SM}=1.0)$ which could be achieved with powder activator only.

Table 5. Mix proportions of fly ash/GGBS mortars with $A M=1.25$ for Series I.

\begin{tabular}{lcccc}
\hline \multicolumn{1}{c}{ Parameter } & $\mathbf{6 0 - 1 . 2 5 - 6 5 - 3 3 0}$ & $\mathbf{6 0 - 1 . 2 5 - 8 0 - 3 3 0}$ & $\begin{array}{c}\text { Control } \\
\text { (Commercial SS) }\end{array}$ & NaOH only \\
\hline $\mathrm{M}+(\%)$ & 7.5 & 7.5 & 7.5 & 7.5 \\
$\mathrm{AM}(-)$ & 1.25 & 1.25 & 1.25 & $\infty$ \\
EF $(\%)$ & $75 \%$ & $90 \%$ & $100 \%$ & $100 \%$ \\
w/s ratio (-) & 0.387 & 0.387 & 0.385 & 0.386 \\
Fly ash $\left(\mathrm{kg} / \mathrm{m}^{3}\right)$ & 316.6 & 318.5 & 323.1 & 330.3 \\
GGBS $\left(\mathrm{kg} / \mathrm{m}^{3}\right)$ & 211.1 & 212.3 & 215.5 & 220.2 \\
Sand $\left(\mathrm{kg} / \mathrm{m}^{3}\right)$ & 1451.1 & 1459.8 & 1480.6 & 1513.9 \\
Act. powder $\left(\mathrm{kg} / \mathrm{m}^{3}\right)$ & 95.3 & 79.9 & - & - \\
SS solution $\left(\mathrm{kg} / \mathrm{m}^{3}\right)$ & - & - & 126.7 & - \\
NaOH solution $\left(\mathrm{kg} / \mathrm{m}^{3}\right)$ & 29.5 & 29.7 & 103.3 & 178.4 \\
Added water $\left(\mathrm{kg} / \mathrm{m}^{3}\right)$ & 211.1 & 212.3 & 86.1 & 103.5 \\
\hline
\end{tabular}




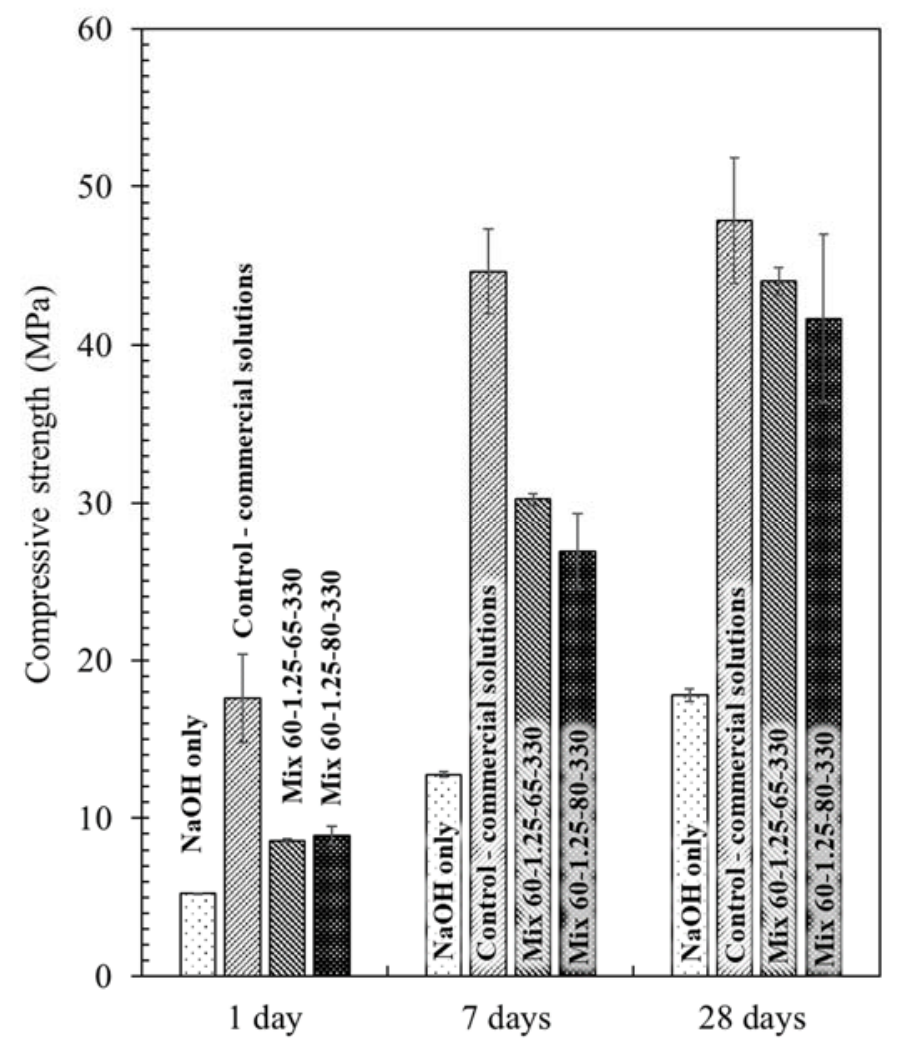

Fig. 7. Compressive strength results of Series I mortar cubes.

Series II: $60 \% / 40 \%$ fly ash/GGBS mixes with $A M=1.0$. A "one-part" alkali activated binder production (i.e. dry mix of precursor/activator blend with only add water needed) becomes possible with the powder activator if AM $=1.0(\mathrm{SM}=1.0)$ and not higher is what is required. Table 6 shows the mix proportions of $60 \% / 40 \%$ fly ash $/ \mathrm{GGBS}$ binder blends investigated and Figure 8 shows the compressive strengths at 1, 7 and 28 days.

The powder activator was dissolved in water for mixes with EF of $70 \%$ and $90 \%$. The mix with EF of $70 \%$ was repeated but with the powder activator added directly to the mixer in solid form. 
Table 6. Mix proportions of fly ash/GGBS mortars with AM = 1.0 for Series II.

\begin{tabular}{lrrrrr}
\hline \multicolumn{1}{c}{ Parameter } & $\mathbf{6 0 - 1 . 0 - 6 5 - 3 3 0}$ & $\mathbf{6 0 - 1 . 0 - 6 5 s - 3 3 0}$ & $\mathbf{6 0 - 1 . 0 - 8 0 - 3 3 0}$ & $\begin{array}{c}\text { Control } \\
\text { (Commercial SS) }\end{array}$ & NaOH only \\
\hline $\mathrm{M}+(\%)$ & 7.5 & 7.5 & 7.5 & 7.5 & 7.5 \\
$\mathrm{AM}(-)$ & 1.0 & 1.0 & 1.0 & 1.0 & $\infty$ \\
$\mathrm{EF}(\%)$ & $70 \%$ & $70 \%$ & $90 \%$ & $100 \%$ & $100 \%$ \\
w/s ratio $(-)$ & 0.386 & 0.386 & 0.386 & 0.385 & 0.386 \\
Fly ash $\left(\mathrm{kg} / \mathrm{m}^{3}\right)$ & 312.5 & 312.5 & 315.8 & 321.4 & 330.3 \\
GGBS $\left(\mathrm{kg} / \mathrm{m}^{3}\right)$ & 208.3 & 208.3 & 210.5 & 214.3 & 220.2 \\
Sand $\left(\mathrm{kg} / \mathrm{m}^{3}\right)$ & 1432.2 & 1432.2 & 1447.4 & 1473.1 & 1513.9 \\
Act. powder $\left(\mathrm{kg} / \mathrm{m}^{3}\right)$ & 126.0 & 126.0 & 99.0 & - & - \\
SS solution $\left(\mathrm{kg} / \mathrm{m}^{3}\right)$ & - & - & - & 157.6 & - \\
NaOH solution $\left(\mathrm{kg} / \mathrm{m}^{3}\right)$ & - & - & - & 86.8 & 178.4 \\
Added water $\left(\mathrm{kg} / \mathrm{m}^{3}\right)$ & 231.2 & 231.2 & 233.7 & & 103.5 \\
\hline
\end{tabular}

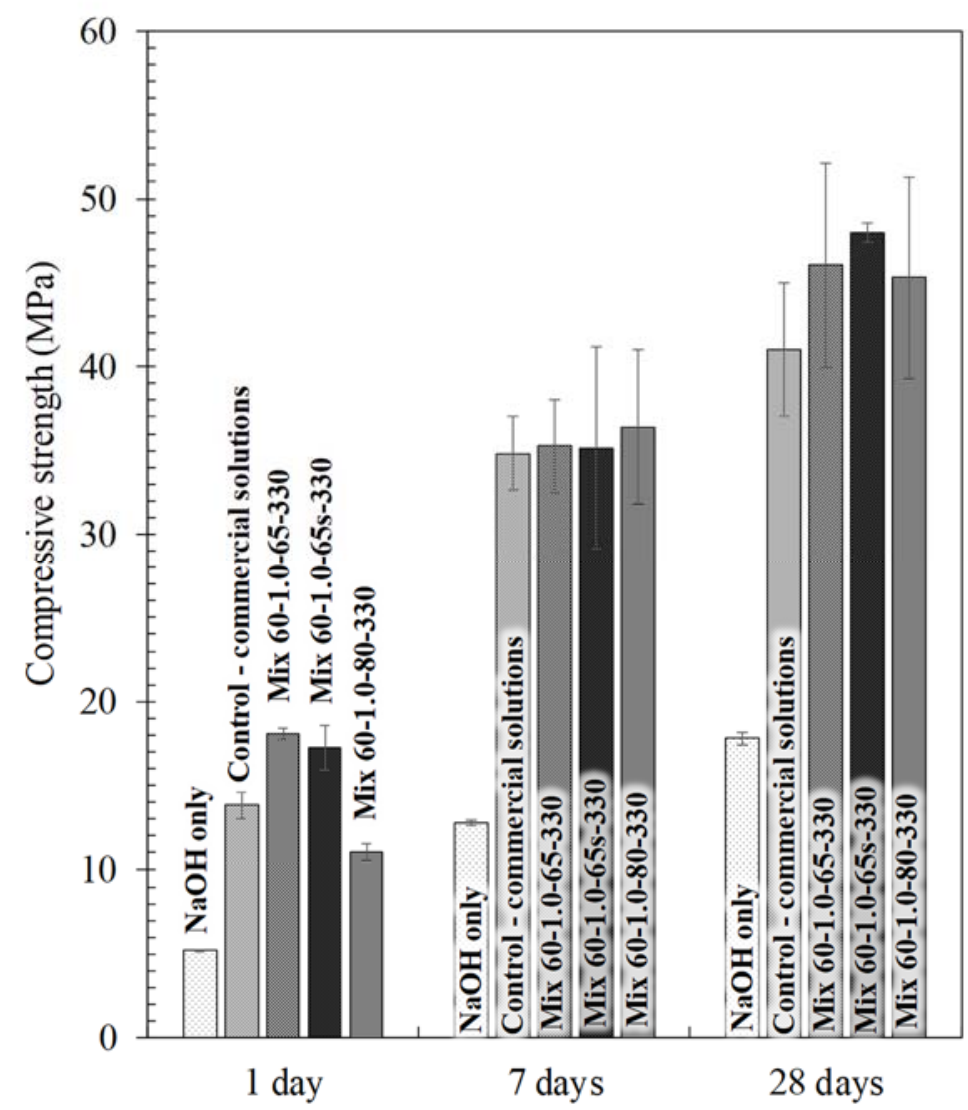

Fig. 8. Compressive strength results of Series II mortar cubes.

Despite the different EF of 65 and $80 \%$, and thus different quantities of powder activator, similar compressive strengths were obtained which exceeded the strength of the control mix which had the commercially available sodium silicate. Mixes with EF of $80 \%$ gave slightly lower strength at 1-day but comparable strengths at 7- and 
28-days. This result was surprising, since it was expected that increasing the powder content would have led to an increase in the compressive strength, as the $\mathrm{M}+$ should have increased. However, for room temperature cured mixes the reaction is driven by the GGBS and the relatively low sensitivity of GGBS to variations in M+ in the investigated range could explain this result [47]. Further investigations are however needed to confirm this.

Adding the powder activator to the mix in solid form just before mixing did not have any adverse effect on the compressive strength. This makes possible a one-part alkali activated binder.

Series III: $100 \%$ fly ash mixes with $A M=1.0$. The previous two series investigated blends of fly ash/GGBS whilst this series aimed at assessing the efficiency factor $(\mathrm{EF})$ with $\mathrm{AM}=1.0(\mathrm{SM}=1)$ of a neat fly ash binder which unlike the previous mixes required curing at $70{ }^{\circ} \mathrm{C}$. Table 7 shows the mortar mix proportions and Figure 9 shows the compressive strengths at 1,7 and 28 days.

Table 7. Mix proportions of neat fly ash mortars with $\mathrm{AM}=1.0$ for Series III (cured at $70{ }^{\circ} \mathrm{C}$ ).

\begin{tabular}{lrrrr}
\hline \multicolumn{1}{c}{ Parameter } & $\mathbf{1 0 0 - 1 0 - 6 5 - 3 3 0}$ & $\mathbf{1 0 0 - 1 0 - 8 0 - 3 3 0}$ & $\begin{array}{c}\text { Control } \\
\text { (Commercial SS) }\end{array}$ & NaOH only \\
\hline $\mathrm{M}+(\%)$ & 7.5 & 7.5 & 7.5 & 7.5 \\
$\mathrm{AM}(-)$ & 1.0 & 1.0 & 1.0 & $\infty$ \\
EF $(\%)$ & $70 \%$ & $90 \%$ & $100 \%$ & $100 \%$ \\
w/s ratio $(-)$ & 0.370 & 0.370 & 0.371 & 0.371 \\
Fly ash $\left(\mathrm{kg} / \mathrm{m}^{3}\right)$ & 518.0 & 523.5 & 532.2 & 546.8 \\
GGBS $\left(\mathrm{kg} / \mathrm{m}^{3}\right)$ & - & - & - & - \\
Sand $\left(\mathrm{kg} / \mathrm{m}^{3}\right)$ & 1424.5 & 1439.6 & 1463.5 & 1503.7 \\
Act. powder $\left(\mathrm{kg} / \mathrm{m}^{3}\right)$ & 125.3 & 98.5 & - & - \\
SS solution $\left(\mathrm{kg} / \mathrm{m}^{3}\right)$ & - & - & 156.5 & - \\
NaOH solution $\left(\mathrm{kg} / \mathrm{m}^{3}\right)$ & - & - & 86.2 & 177.2 \\
Added water $\left(\mathrm{kg} / \mathrm{m}^{3}\right)$ & 220.7 & 223.0 & 71.3 & 94.0 \\
\hline
\end{tabular}




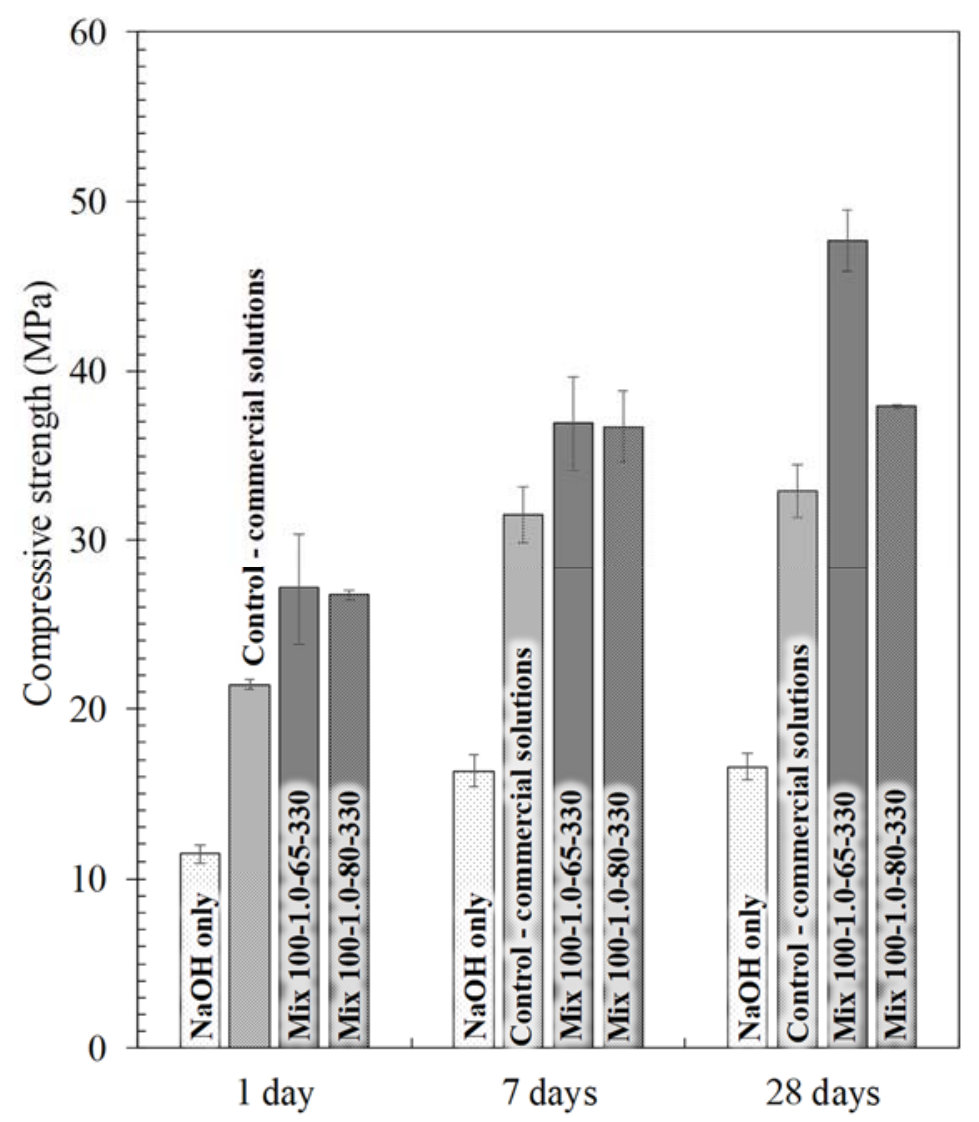

Fig. 9. Compressive strength results of Series III mortar cubes.

The mortar strengths of neat fly ash mixes (cured at $70{ }^{\circ} \mathrm{C}$ ) using the powder activator assuming EF of $65 \%$ and $80 \%$ were higher than the control mixes. The efficiency of the powder activator has again been shown to be nearly equal to the commercially available ones. As previously discussed, the use of a lower EF implies more powder activator, and therefore potentially increasing the $\mathrm{M}+$ of the mix if the EF assumed is not correct. For example, the amount of powder activator used for an EF of $65 \%$ would lead to an $\mathrm{M}+$ exceeding $9.5 \%$ if the actual EF is $80 \%$ instead. The 28-day compressive strength would therefore be expected to be higher than the control whose $\mathrm{M}+$ is only $7.5 \%$. This confirms that an EF of about $80 \%$ is reasonable.

Series IV: fly ash/GGBS and fly ash mixes with powder processed at $150{ }^{\circ} \mathrm{C}$. The aim of series IV was to assess the efficiency of the powder activator produced at $150{ }^{\circ} \mathrm{C}$ rather than at $330{ }^{\circ} \mathrm{C}$. Both $60 \% / 40 \%$ fly ash/GGBS blends and neat fly ash mixes were investigated. The efficiency factor (EF) was assumed to be $65 \%$. Perhaps, with hindsight, an EF equal to $80 \%$ should have been more appropriate. This was not possible as series IV was done at the same time as series III. Table 8 shows the mix proportions and Figure 10 shows the compressive strengths. 
Results from mixes 60-1.0-65-330 and 100-1.0-65-330 (discussed earlier) as well as those of the control mixes are also shown for comparison.

The 1- and 7-day strengths of mortars with powder activator produced at $150{ }^{\circ} \mathrm{C}$ were similar to the strengths of mortars with powder activator produced at $330^{\circ} \mathrm{C}$. However, at 28 days, fly ash/GGBS mortars with powder activator produced at $150{ }^{\circ} \mathrm{C}$ had significantly higher strengths than the mortars with powder activator produced at $330{ }^{\circ} \mathrm{C}$, whilst the opposite was observed for neat fly ash samples. This aspect would require further investigation.

Table 8. Mix proportions for mortars with activator powder produced at $150{ }^{\circ} \mathrm{C}$.

\begin{tabular}{lcc}
\hline \multicolumn{1}{c}{ Parameter } & $\mathbf{6 0 - 1 . 0 - 6 5 - 1 5 0}$ & $\mathbf{1 0 0 - 1 . 0 - 6 5 - 1 5 0}$ \\
\hline $\mathrm{M}+(\%)$ & 7.5 & 7.5 \\
$\mathrm{AM}(-)$ & 1.0 & 1.0 \\
EF $(\%)$ & $70 \%$ & $70 \%$ \\
w/s ratio $(-)$ & 0.386 & 0.370 \\
Fly ash $\left(\mathrm{kg} / \mathrm{m}^{3}\right)$ & 312.5 & 518.0 \\
GGBS $\left(\mathrm{kg} / \mathrm{m}^{3}\right)$ & 208.3 & - \\
Sand $\left(\mathrm{kg} / \mathrm{m}^{3}\right)$ & 1432.2 & 1424.5 \\
Act. powder $\left(\mathrm{kg} / \mathrm{m}^{3}\right)$ & 126.0 & 125.3 \\
SS solution $\left(\mathrm{kg} / \mathrm{m}^{3}\right)$ & - & - \\
NaOH solution $\left(\mathrm{kg} / \mathrm{m}^{3}\right)$ & - & - \\
Added water $\left(\mathrm{kg} / \mathrm{m}^{3}\right)$ & 231.2 & 220.7 \\
\hline
\end{tabular}



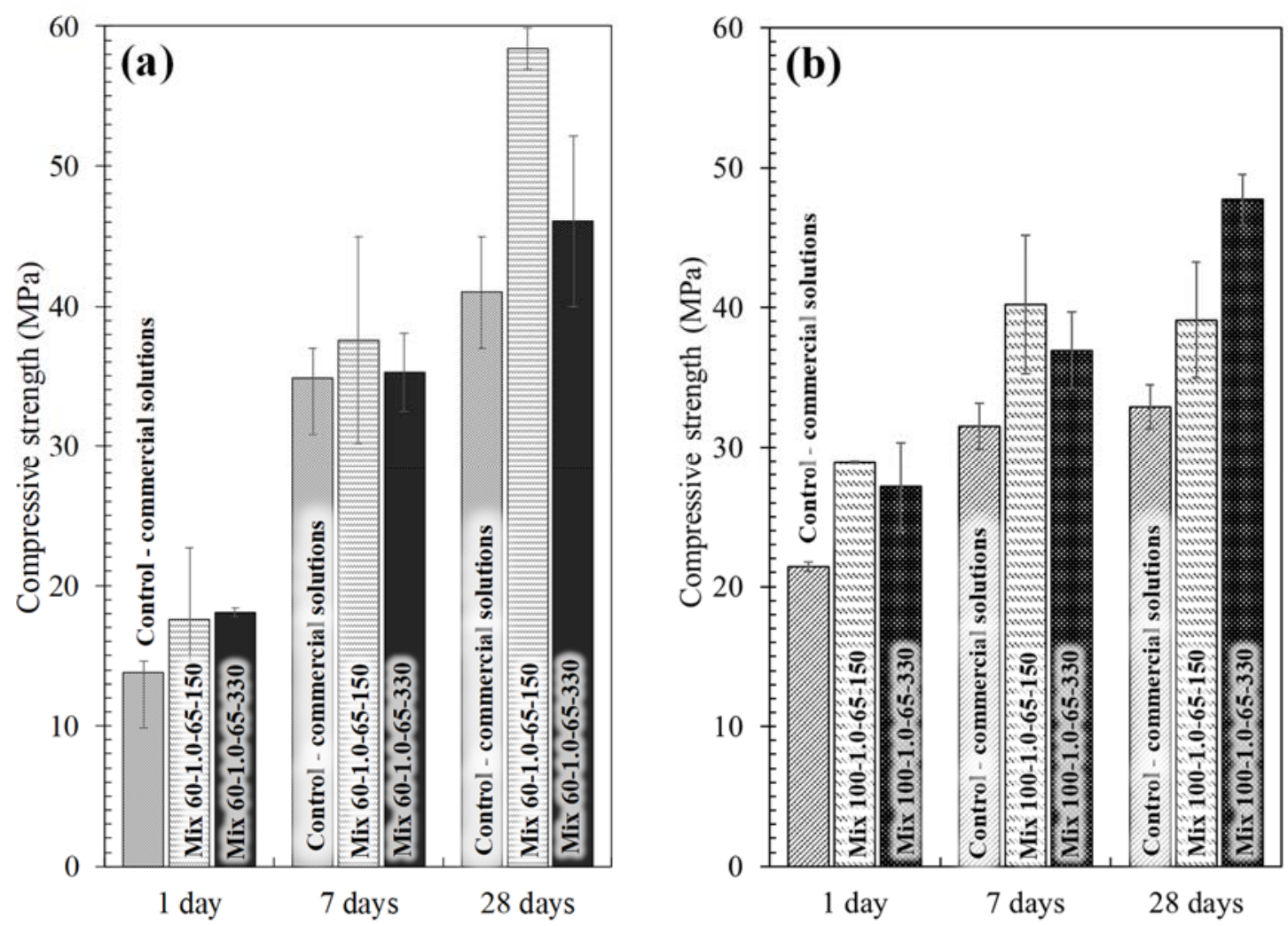

Fig. 10. Series IV. Comparison of mortar compressive strengths with power activator produced at $150{ }^{\circ} \mathrm{C}$ and $330{ }^{\circ} \mathrm{C}$. (a) $60 \% / 40 \%$ fly ash/GGBS mixes; (b) $100 \%$ fly ash mixes.

The above four series of mortar mixes have shown that:

- The powder activators produced with the described thermochemical process were efficient in activating precursors such as fly ash and GGBS which are commonly used in alkali activated binders.

- The actual composition of the powder, the amorphous content and the degree of dissolution in water make accurate estimates of the availability of silicates very difficult. An efficiency factor (EF) of $80 \%$ has been proposed to take into account these uncertainties.

- $\quad$ An $\mathrm{AM}=1.0(\mathrm{SM}=1)$ led to satisfactory strengths without the need for adding sodium hydroxide to increase it to $\mathrm{AM}=1.25(\mathrm{SM}=0.8)$.

- The powder activator was found to be efficient also when added directly to the mix in solid form together with the dry precursor. This makes possible a one-part alkali activated binder requiring only water to be added, i.e. similar to Portland cement.

- The powder activator produced at $150{ }^{\circ} \mathrm{C}$ was found to be as efficient as the one produced at $330{ }^{\circ} \mathrm{C}$. This has considerable savings in terms of the energy requirements and consequently reduces the carbon 
footprint of the powder activators.

Compressive strength tests have shown that the efficiency of the powder activator was very good, contrary to commercially available solid sodium metasilicate (anhydrous or pentahydrate), shown by others [10,12] not to be good in activating powder precursors. This was confirmed in this research with some tests that used powder sodium silicate pentahydrate (commercially available) on mortars with neat fly ash and fly ash/GGBS blends. The powder was either added into the mixer in dry form or pre-dissolved in water, but very low reaction was observed. The dissolution rate was quite slow and there was no heat developed. Less than one third of the expected compressive strength was measured even after 56 days of curing in the case of neat fly ash mortar, and less than half of the expected compressive strength in the case of $60 \% / 40 \%$ fly ash/GGBS mix.

Why the solid sodium metasilicate produced from waste glass powder was found to be reactive was therefore further investigated by a series of infrared spectroscopy tests.

\subsection{FT-IR investigation on the produced powder activator}

FT-IR spectra of powder activators produced at 150,250 and $330{ }^{\circ} \mathrm{C}$ were investigated, comparing these with the ones obtained with commercially available sodium silicate pentahydrate and raw glass powder.

The raw glass powder transmission spectrum shows a main peak corresponding to the $\mathrm{Si}-\mathrm{O}-\mathrm{Si}$ stretching band at $999 \mathrm{~cm}^{-1}$, which for amorphous pure silica should occur in the range of $1100 \mathrm{~cm}^{-1}[48,49]$.

The three powder activators showed a recognisable pattern in their spectra, having a broad hump in the region around $2900 \mathrm{~cm}^{-1}$, which can be attributed to sodium carbonate [50]. No evidence of $-\mathrm{OH}$ bonds (which are usually associated with bands at about $3500 \mathrm{~cm}^{-1}$ and $1650 \mathrm{~cm}^{-1}$ [51]) were observed, which would exclude the presence of unreacted $\mathrm{NaOH}$, confirming the findings from the XRD analysis. Sodium carbonate presence was confirmed by the peak at $1423 \mathrm{~cm}^{-1}[51,52]$. The main peaks were recorded in the range 1025 to $709 \mathrm{~cm}^{-1}$, see Figure 11 .

The addition of alkali cations in silicates results in a destruction of the silicate polymerised network. One of the effects of $\mathrm{Na}$ inclusion which is observed in IR spectra is the shift towards lower wavenumbers of the main peaks associated with Si-O-Si bonds stretching and bending [53 - 56]. The inclusion of alkali metal cations forces the breakdown to Si-O-Si bonds and the formation of Si-O-M (where M is the alkali metal cation) and Si connection with non-bridging oxygen (NBO) $[48,53,57] .$. In amorphous solid silicate, only $\mathrm{Q}^{4}$ groups are present $[30,33]$, whilst in silicate solutions a high quantity of $\mathrm{Q}^{0}$ groups is expected [58-59]. 




Fig. 11. FT-IR spectra of bottle glass and powder activators produced at temperatures of 150,250 and $330{ }^{\circ} \mathrm{C}$.

An increase of alkali concentration in the silica network has been shown by others [53] to give a higher concentration of NBO groups, and their presence is known in the literature to be responsible for improving the dissolution of silica and its availability for the formation of other Si-rich structures $[53,58,60]$.

The presence of peaks that can be attributed to Si-NBO groups in the spectra of processed powder activators could explain their reactivity, as Si would be readily dissolved and available for geopolymerisation reactions. The analysis focused therefore on the sequence of peaks in the bands 1025 to $673 \mathrm{~cm}^{-1}$ observed in all processed powder activators (i.e. irrespective of the process temperature), which might suggest the presence of different species of silicates, i.e. silicate structures with oxygen bonds having different degrees of connectivity. A deconvolution of the spectrum of the powder produced at $330{ }^{\circ} \mathrm{C}$ was tried in order to better appreciate peaks in the range $600-1200 \mathrm{~cm}^{-1}$ wavenumber. However the deconvolution fit was not suitable for a valid interpretation, and therefore the following discussion is to be considered qualitative and not quantitative.

Data available from literature $[11,49,51-59,61]$ were used for identifying peaks corresponding to the different structures. As known, wavenumber decreases with more NBOs present. A strong presence of $\mathrm{Q}^{2}$ groups (at wavenumber positions 964 to $878 \mathrm{~cm}^{-1}$ ) was detected, which could suggest that some of the material was anhydrous sodium metasilicate, which, according to the literature, is composed by a chain of Si-O tetrahedra, each sharing two oxygens with adjacent $\mathrm{Si}-\mathrm{O}$ groups, i.e. $\mathrm{Q}^{2}$ [59]. However, there is also a non-negligible presence of $\mathrm{Q}^{0}-\mathrm{Q}^{1}$ structures, particularly in the band at wavenumber $851 \mathrm{~cm}^{-1}$, which indicates the presence of a certain number of NBO groups which can be responsible for the good reactivity observed. 
From qualitative analysis of the IR spectra of the processed powder activators, it can therefore be concluded that the chemical structure of the obtained powder activators showed a disordered sodium silicate structure with a high number of reactive NBO groups, presumably concentrated on the surface of the powder grains, which allow the fast dissolution (and availability for reaction) of $\mathrm{Si}$.

\subsection{Cost analysis}

Mix proportions for three concretes of 28-day mean compressive strengths of 35, 50 and $70 \mathrm{MPa}$, described in [62], were used for estimating the costs per cubic metre when (a) commercially available activators and (b) powder activators were used. These were compared with equivalent strength Portland cement concretes. Compressive strength, initial setting time and initial consistency were comparable among alkali activated concretes (AAC) and Portland cement concretes. Unit costs of the constituents used for estimating the unit cost of a cubic metre of concrete are shown in Tables 9 to 11 .

The powder activator costs were estimated for the thermochemical process described above which involved heating a mix of $\mathrm{NaOH}$ and glass powder with mass proportions $48 \%$ / $52 \%$ at $150{ }^{\circ} \mathrm{C}$ to $330{ }^{\circ} \mathrm{C}$ for one to two hours. One hour duration has been shown to be sufficient. However, the following analysis considers two hours of heating in order to incorporate possible longer heating time that may be needed for larger quantities likely to be processed when upscaling the process from laboratory to industrial scale.

The costs associated with the production of the powder activator are:

(a) Cost of raw materials (glass cullet and powder $\mathrm{NaOH}$ ). Cost of $\mathrm{NaOH}$ has been estimated to be $200 £ / \mathrm{t}$ from data available on industrial trading websites. Considering the required mass proportion, cost of $\mathrm{NaOH}$ per tonne of activator powder is about $£ 96$. The glass powder has been assumed to be available for free at source and no transportation costs have been considered. Glass powder is available from bottle recycling plants and it is currently considered to be a waste. The energy requirements for grinding the glass in case the material is available in cullet form has been estimated to be $50 \mathrm{kWh} / \mathrm{t}$, as average (conservative) value obtained from technical specifications (installed power vs capacity) of industrial grinding equipment. $26 \mathrm{kWh}$ would therefore be required for grinding, which will add an extra $4 £ / t$ when considering energy cost of $£ 0.15$ per $\mathrm{kWh}$.

(b) Cost of energy for the heating process. Large cabinet ovens (700 1 capacity) might process 1 tonne of powder per batch. The power consumption has been estimated to be 6 to $10 \mathrm{~kW}$ according to the technical specifications obtained for industrial ovens with the required capacity. It is therefore estimated that 20 
$\mathrm{kWh}$ is the energy required for processing 1 tonne of material. A heating cost of $3 \mathfrak{f} / \mathrm{t}$ is considered reasonable on the basis of $£ 0.15$ per $\mathrm{kWh}$.

Based on the above, the production cost for the powder activator was estimated to be in the range of $100 £ / t$ (out of which about $95 \%$ is due to $\mathrm{NaOH}$ cost).

Table 9. Cost analysis for Concrete 1 - target 28-day mean strength of $35 \mathrm{MPa}$.

\begin{tabular}{|c|c|c|c|c|c|c|c|c|c|c|}
\hline \multirow[t]{2}{*}{ Constituent } & \multirow[t]{2}{*}{$\mathfrak{f} / \mathbf{t}$} & \multicolumn{3}{|c|}{$\begin{array}{c}\text { AAC with commercial } \\
\text { activators }\end{array}$} & \multicolumn{3}{|c|}{$\begin{array}{l}\text { Portland cement } \\
\text { concrete }\end{array}$} & \multicolumn{3}{|c|}{$\begin{array}{c}\text { AAC with activator } \\
\text { powder }\end{array}$} \\
\hline & & $\mathrm{kg}$ & $£$ & $\%$ & $\mathrm{~kg}$ & $£$ & $\%$ & $\mathrm{~kg}$ & $£$ & $\%$ \\
\hline Portland Cement & 70 & - & - & - & 355.0 & 24.85 & $57 \%$ & - & - & - \\
\hline Fly ash & 40 & 283.2 & 11.33 & $18 \%$ & - & - & - & 283.2 & 11.33 & $27 \%$ \\
\hline GGBS & 65 & 70.8 & 4.60 & $7 \%$ & - & - & - & 70.8 & 4.60 & $11 \%$ \\
\hline Sodium silicate solution & 300 & 83.3 & 24.99 & $39 \%$ & - & - & - & - & - & - \\
\hline Activating powder & 100 & - & - & - & - & - & - & 66.6 & 6.66 & $16 \%$ \\
\hline $\mathrm{NaOH}$ & 200 & 20.5 & 4.10 & $6 \%$ & - & - & - & - & - & - \\
\hline Water & 1 & 105.9 & 0.11 & $0 \%$ & 220.0 & 0.22 & $1 \%$ & 158.8 & 0.16 & $0 \%$ \\
\hline Aggregate & 10 & 1897.5 & 18.98 & $30 \%$ & 1832.0 & 18.32 & $42 \%$ & 1897.5 & 18.98 & $45 \%$ \\
\hline Total & & 2461.2 & 64.10 & $100 \%$ & 2407.0 & 43.39 & $100 \%$ & 2476.9 & 41.72 & $100 \%$ \\
\hline
\end{tabular}

Table 10. Cost analysis for Concrete 2 - target 28-day mean strength of $50 \mathrm{MPa}$.

\begin{tabular}{|c|c|c|c|c|c|c|c|c|c|c|}
\hline \multirow{2}{*}{ Constituent } & \multirow[t]{2}{*}{$\mathfrak{f} / \mathbf{t}$} & \multicolumn{3}{|c|}{$\begin{array}{c}\text { AAC with commercial } \\
\text { activators }\end{array}$} & \multicolumn{3}{|c|}{$\begin{array}{l}\text { Portland cement } \\
\text { concrete }\end{array}$} & \multicolumn{3}{|c|}{$\begin{array}{l}\text { AAC with activator } \\
\text { powder }\end{array}$} \\
\hline & & $\mathrm{kg}$ & $£$ & $\%$ & $\mathrm{~kg}$ & $£$ & $\%$ & $\mathrm{~kg}$ & $£$ & $\%$ \\
\hline Portland Cement & 70 & - & - & - & 440.0 & 30.80 & $63 \%$ & - & - & - \\
\hline Fly ash & 40 & 258.3 & 10.33 & $15 \%$ & - & - & - & 258.3 & 10.33 & $24 \%$ \\
\hline GGBS & 65 & 110.7 & 7.20 & $11 \%$ & - & - & - & 110.7 & 7.20 & $17 \%$ \\
\hline Sodium silicate solution & 300 & 86.8 & 26.04 & $39 \%$ & - & - & - & - & - & - \\
\hline Activating powder & 100 & - & - & - & - & - & - & 69.4 & 6.94 & $16 \%$ \\
\hline $\mathrm{NaOH}$ & 200 & 21.4 & 4.28 & $6 \%$ & - & - & - & - & - & - \\
\hline Water & 1 & 102.0 & 0.10 & $0 \%$ & 220.0 & 0.22 & $0 \%$ & 157.0 & 0.16 & $0 \%$ \\
\hline Aggregate & 10 & 1897.5 & 18.98 & $28 \%$ & 1750.0 & 17.50 & $36 \%$ & 1897.5 & 18.98 & $44 \%$ \\
\hline Total & & 2476.7 & 66.92 & $100 \%$ & 2410.0 & 48.52 & $100 \%$ & 2492.9 & 43.60 & $100 \%$ \\
\hline
\end{tabular}


Table 11. Cost analysis for Concrete 3 - target 28-day mean strength of $70 \mathrm{MPa}$.

\begin{tabular}{|c|c|c|c|c|c|c|c|c|c|c|}
\hline \multirow[t]{2}{*}{ Constituent } & \multirow[t]{2}{*}{$\mathfrak{f} / \mathbf{t}$} & \multicolumn{3}{|c|}{$\begin{array}{l}\text { AAC with commercial } \\
\text { activators }\end{array}$} & \multicolumn{3}{|c|}{$\begin{array}{l}\text { Portland cement } \\
\text { concrete }\end{array}$} & \multicolumn{3}{|c|}{$\begin{array}{l}\text { AAC with activator } \\
\text { powder }\end{array}$} \\
\hline & & $\mathrm{kg}$ & $£$ & $\%$ & $\mathrm{~kg}$ & $£$ & $\%$ & $\mathrm{~kg}$ & $£$ & $\%$ \\
\hline Portland Cement & 70 & & 0.00 & $0 \%$ & 550.0 & 38.50 & $69 \%$ & & 0.00 & $0 \%$ \\
\hline Fly ash & 40 & 99.0 & 3.96 & $6 \%$ & & 0.00 & $0 \%$ & 99.0 & 3.96 & $9 \%$ \\
\hline GGBS & 65 & 231.0 & 15.02 & $23 \%$ & & 0.00 & $0 \%$ & 231.0 & 15.02 & $34 \%$ \\
\hline Sodium silicate solution & 300 & 77.6 & 23.28 & $36 \%$ & & 0.00 & $0 \%$ & & 0.00 & $0 \%$ \\
\hline Activating powder & 100 & & 0.00 & $0 \%$ & & 0.00 & $0 \%$ & 62.1 & 6.21 & $14 \%$ \\
\hline $\mathrm{NaOH}$ & 200 & 19.1 & 3.82 & $6 \%$ & & 0.00 & $0 \%$ & & 0.00 & $0 \%$ \\
\hline Water & 1 & 121.2 & 0.12 & $0 \%$ & 220.0 & 0.22 & $0 \%$ & 170.8 & 0.17 & $0 \%$ \\
\hline Aggregate & 10 & 1925.0 & 19.25 & $29 \%$ & 1668.0 & 16.68 & $30 \%$ & 1925.0 & 19.25 & $43 \%$ \\
\hline Total & & 2472.9 & 65.45 & $100 \%$ & 2438.0 & 55.40 & $100 \%$ & 2487.9 & 44.61 & $100 \%$ \\
\hline
\end{tabular}

As shown in Tables 9 to 11, the alkali activated concrete produced with commercially sourced activators is considerably more expensive than the equivalent Portland cement concrete. Cost differences vary from $48 \%$ for the normal strength concrete - Concrete 1, decreasing to $18 \%$ for high strength concrete - Concrete 3 . On the contrary, alkali activated concrete produced with the powder activator has a slightly lower cost than Portland cement concrete (4\%) for normal strengths, and it is cheaper by $10 \%$ and $19 \%$ for $50 \mathrm{MPa}$ and $70 \mathrm{MPa} 28$-day strength concretes respectively.

The cost of activator is between $41 \%$ and $45 \%$ of the total cost of alkali activated concretes when commercially available activators are used but it is only between $14 \%$ and $16 \%$ when the powder activator is used.

\section{Conclusions}

The development of a low cost and with a low environmental carbon footprint powder activator has been described. This is an alternative to the currently commercially available ones. The cost of currently available commercials activators is hindering the commercialisation of AAB concretes. Commercially available activators are not only expensive but also come in liquid form which has health and safety implications in their handling on site.

Main results from the investigation can be summarised as follows:

- A procedure for the production of a powder activator, composed mainly of reactive sodium silicate has been developed. This involves blending glass powder and sodium hydroxide in mass proportions of $48 \%$ / $52 \%$, adding water to produce a paste and then heating the mixture in an oven at $150{ }^{\circ} \mathrm{C}$ to $330{ }^{\circ} \mathrm{C}$ for 1 to 2 hours.

- The efficiency of the developed powder activator was compared with commercially available activators 
by comparing compressive strength of mortars produced with different precursors (a blend of fly ash/GGBS on the one hand and neat fly ash on the other). The efficiency of the powder activator in activating fly ash and fly ash/GGBS binders was shown to be around $80 \%$. This is based on the fact that compressive strengths of mortars produced with the developed powder activator had similar strengths to those of control mixes produced with commercially available activators.

- Microstructural investigation on the powder activator suggested that it was sodium metasilicate with a disordered structure showing a significant presence of $\mathrm{Q}^{0}$ and $\mathrm{Q}^{1}$ type silicate. This indicates high solubility and reactivity.

- $\quad$ The cost of concretes produced with the developed powder activator were comparable, if not cheaper, than equivalent Portland cement concretes. The developed powder activator is also expected to have a much lower carbon footprint.

In order to corroborate the results obtained, further work is envisaged in the near future, which will determine more accurately the solubility of $\mathrm{SiO}_{2}$ under the different conditions employed. The optimisation of the production step will also investigate suitable methods for the recovery of water used for the treatment, in line with EU strategy for future industrial processes with no waste.

Microstructural characterisation of pastes produced with the developed powder activator is continuing in order to determine the reaction products and whether these differ from those obtained when commercially available liquid activators are used. Porosity and pore size distribution of pastes will also be investigated.

\section{Acknowledgements}

The authors would like to thank Innovate UK-EPSRC for providing funding for the project RESCIND "REcovery and uSe of Cement kIIN Dust as the alkali activator for Geopolymeric (Cementless) Concrete Building Blocks", Grant Ref. EP/N508962/1. The authors are also grateful to Prof Kenneth R. Seddon and Dr Natalia Plechkova for their invaluable advice and guidance in developing the thermochemical process described in this paper. The assistance of Dr Susan Lawther with the fly ash mixes, Series III, is also gratefully acknowledged.

\section{References}

[1] J.L. Provis, Alkali-activated materials. Cement and Concrete Research. Article in press, http://dx.doi.org/10.1016/j.cemconres.2017.02.009 (2017)

[2] M. Fawer, M. Concannon, W. Rieber, Life cycle inventories for the production of sodium silicates. The International Journal of Life Cycle Assessment, 4(4) (1999) 207-212. 
[3] F. Pacheco-Torgal, J.P. Castro-Games, S. Jalali, Alkali activated geopolymeric binder using tungsten mine waste: preliminary investigation. In Geopolymer, Green Chemistry and Sustainable Development Solutions. France, (2005) 93-98.

[4] B. Tempest, O. Sanusi, J. Gergely, V. Ogunro, D. Weggel, Compressive strength and embodied energy optimization of fly ash based geopolymer concrete. In world of coal ash (WOCA) conference, (2009) 1-17.

[5] R. Witherspoon, H. Wang, T. Aravinthan, T. Omar, Energy and emissions analysis of fly ash based geopolymers. SSEE 2009: Solutions for a Sustainable Planet (2009)

[6] B.C. McLellan, R.P. Williams, J. Lay, A. Van Riessen, G.D. Corder, Costs and carbon emissions for geopolymer pastes in comparison to ordinary portland cement. Journal of Cleaner Production, 19(9) (2011) 1080-1090.

[7] F.K. Crundwell, On the Mechanism of the Dissolution of Quartz and Silica in Aqueous Solutions. ACS Omega, 2(3), (2017) 1116-1127.

[8] E. McGuire, J.L. Provis, P. Duxson, R. Crawford, Geopolymer concrete is there an alternative and viable technology in the concrete sector which reduces carbon emissions. Proceedings concrete, 11 (2011).

[9] G. Habert, C. Ouellet-Plamondon, Recent update on the environmental impact of geopolymers. RILEM technical Letters, 1, (2016) 17-23.

[10] T. Luukkonen, Z. Abdollahnejad, J. Yliniemi, P. Kinnunen, M. Illikainen, One-part alkali-activated materials: A review. Cement and Concrete Research, 103 (2017) 21-34.

[11] J.R. Falcone Jr, J.L. Bass, M. Angelella, E.R. Schenk, K.A. Brensinger, The determination of sodium silicate composition using ATR FT-IR. Industrial \& Engineering Chemistry Research, 49(14) (2010) 62876290.

[12] C. Rees, G.C., Lukey, J.S.J. Van Deventer, The microstructural characterization of geopolymers derived from fly ash and solid silicates. In Geopolymer, Green Chemistry and Sustainable Development Solutions: Proceedings of the World Congress Geopolymer 2005 (p. 61) (2005). Geopolymer Institute.

[13] V. Živica, Effectiveness of new silica fume alkali activator. Cement and Concrete Composites, 28(1) (2006) 21-25.

[14] E.D. Rodríguez, S.A. Bernal, J.L. Provis, J. Paya, J.M. Monzo, M.V. Borrachero, Effect of nanosilicabased activators on the performance of an alkali-activated fly ash binder. Cement and Concrete Composites, 35(1) (2013) 1-11.

[15] S.A. Bernal, E.D. Rodríguez, R.M. de Gutiérrez, J.L. Provis, S. Delvasto, Activation of metakaolin/slag blends using alkaline solutions based on chemically modified silica fume and rice husk ash. Waste and Biomass Valorization, 3(1) (2012) 99-108.

[16] S.A. Bernal, E.D. Rodríguez, R.M. de Gutiérrez, J.L. Provis, Performance at high temperature of alkaliactivated slag pastes produced with silica fume and rice husk ash based activators. Materiales de Construcción, 65(318) (2015). 
[17] H.K. Tchakouté, C.H. Rüscher, S. Kong, E. Kamseu, C. Leonelli, Geopolymer binders from metakaolin using sodium waterglass from waste glass and rice husk ash as alternative activators: A comparative study, Construction and Building Materials, 114 (2016) 276-289.

[18] K.T. Tong, R. Vinai, M.N. Soutsos, Use of Vietnamese rice husk ash for the production of sodium silicate as the activator for alkali-activated binders. Journal of Cleaner Production, 201 (2018), 272-286.

[19] A. Passuello, E.D. Rodríguez, E. Hirt, M. Longhi, S.A. Bernal, J.L. Provis, A,P, Kirchheim, Evaluation of the potential improvement in the environmental footprint of geopolymers using waste-derived activators. Journal of Cleaner Production, 166 (2017) 680-689.

[20] G.A. Blengini, M. Busto, M. Fantoni, D. Fino, Eco-efficient waste glass recycling: Integrated waste management and green product development through LCA. Waste management, 32(5) (2012) 1000-1008.

[21] J. Flanagan, M. Davies, Glass recycling-life cycle carbon dioxide emissions. A Life Cycle Analysis Report prepared for British Glass by Enviros Consulting Ltd

http://www.packagingfedn.co.uk/images/reports/Enviros_Report.pdf (2003) (accessed 22 December 2017)

[22] FEVE, Federação dos vidros de embalagem da Europa. Estatísticas. http://feve.org/wpcontent/uploads/2016/10/FEVE-2014-target.jpg (2014) (accessed 22 December 2017)

[23] H. Rashidian-Dezfouli, P.R. Rangaraju, V.S.K. Kothala, Influence of selected parameters on compressive strength of geopolymer produced from ground glass fiber. Construction and Building Materials, 162 (2018) $393-405$.

[24] S. Zhang, A. Keulen, K. Arbi, G. Ye, G, Waste glass as partial mineral precursor in alkali-activated slag/fly ash system. Cement and Concrete Research, 102 (2017) 29-40.

[25] R. Novotny, A. Hoff, J. Schuertz, J. Process for hydrothermal production of sodium silicate solutions. U.S. Patent 5,000,933 (1991).

[26] G. Modica, Process of treating end-of-life cathode ray tubes for lead and soluble silicates recovery. U.S. Patent Application 13/692,136 (2012).

[27] F. Puertas, T.J.D. Torres, C. Varga, Method for the production of alkali cements from industrial and urban waste glass. WO2012172138A1 (2012).

[28] D.B. Hawkins, Kinetics of glass dissolution and zeolite formation under hydrothermal conditions. Clays and Clay Minerals, 29(5) (1981) 331-340.

[29] P.M. Dove, N. Han, A.F. Wallace, J.J. De Yoreo, Kinetics of amorphous silica dissolution and the paradox of the silica polymorphs. Proceedings of the National Academy of Sciences, 105(29) (2008) 9903-9908.

[30] Y. Niibori, M. Kunita, O. Tochiyama, T. Chida,. Dissolution rates of amorphous silica in highly alkaline solution. Journal of Nuclear Science and Technology, 37(4) (2000) 349-357.

[31] S.S. Kouassi, J. Andji, J.P. Bonnet, S. Rossignol, Dissolution of waste glasses in high alkaline solutions. Ceramics-Silikáty, 54(3) (2010) 235-240. 
[32] G. Di Bella, I. Arrigo, P. Catalfamo, F. Corigliano, L. Mavilia, Advances in the extraction of silica from glass cullet. In Recycl Reuse Waste Mater Proc Int Symp, (2003) 137-142.

[33] F. Puertas, M. Torres-Carrasco, Use of glass waste as an activator in the preparation of alkali-activated slag. Mechanical strength and paste characterisation. Cement and Concrete Research, 57 (2014) 95-104.

[34] M. Torres-Carrasco, F. Puertas, Waste glass in the geopolymer preparation. Mechanical and microstructural characterisation. Journal of Cleaner Production, 90 (2015) 397-408.

[35] M. Torres-Carrasco, J.G. Palomo, F. Puertas, Sodium silicate solutions from dissolution of glasswastes. Statistical analysis. Materiales de Construcción, 64(314) (2014).

[36] F. Puertas, M. Torres-Carrasco, M. Alonso, Reuse of urban and industrial waste glass as novel activator for alkali-activated slag cement pastes: A case study. In Handbook of alkali-activated cements, mortars and concretes, Woodhead Publishing, United Kingdom, (2014) p.75.

[37] M. Torres-Carrasco, F. Puertas, Re-use of waste glass as alkaline activator in the preparation of alkaliactivated materials. In 34th Annual Cement and Concrete Science Conference, 14-16 September 2014 University of Sheffield, (2014) 207-210

[38] M. Torres-Carrasco, C. Rodríguez-Puertas, M. del Mar Alonso, F. Puertas, Alkali activated slag cements using waste glass as alternative activators. Rheological behaviour. Boletín de la Sociedad Española de Cerámica y Vidrio, 54(2) (2015) 45-57.

[39] H. Mori, Extraction of silicon dioxide from waste colored glasses by alkali fusion using sodium hydroxide. Journal of the Ceramic Society of Japan, 111(1294) (2003) 376-381.

[40] M. Keawthun, S. Krachodnok, A. Chaisena, Conversion of waste glasses into sodium silicate solutions. Int. J. Chem. Sci., 12(1) (2014) 83-91

[41] B. Hu, S. Zhao, S. Zhang, Removal of lead from cathode ray tube funnel glass by generating the sodium silicate. Journal of the Air \& Waste Management Association, 65(1) (2015) 106-114.

[42] E. Negre, V. Motto-Ros, F. Pelascini, S. Lauper, D. Denis, J. Yu, On the performance of laser-induced breakdown spectroscopy for quantitative analysis of minor and trace elements in glass. Journal of Analytical Atomic Spectrometry, 30(2) (2015) 417-425.

[43] M. Tiainen, J. Daavitsainen, R.S. Laitinen, The role of amorphous material in ash on the agglomeration problems in FB boilers. A powder XRD and SEM-EDS study. Energy \& fuels, 16(4), (2002) 871-877.

[44] M.D. Allendorf, K.E. Spear, Thermodynamic analysis of silica refractory corrosion in glass-melting furnaces. Journal of the electrochemical society, 148(2) (2001) B59-B67.

[45] A.B. Meshalkin, A.B. Kaplun, Phase equilibria in the $\mathrm{Na}_{2} \mathrm{O}-\mathrm{SiO}_{2}$ system. Russ. J. Inorg. Chem, 48 (2003) 1567-1569.

[46] J. Lee, J. Lee, T. Tanaka, H. Mori, In situ atomic-scale observation of melting point suppression in nanometer-sized gold particles. Nanotechnology, 20(47) (2009). 
[47] M. Soutsos, A.P. Boyle, R. Vinai, A. Hadjierakleous, S.J. Barnett, Factors influencing the compressive strength of fly ash based geopolymers. Construction and Building Materials, 110 (2016) 355-368.

[48] J.R. Ferraro, M.H. Manghnani, Infrared absorption spectra of sodium silicate glasses at high pressures. Journal of Applied Physics, 43(11) (1972) 4595-4599.

[49] M.E. Simonsen, C. Sønderby, Z. Li, E.G. Søgaard, XPS and FT-IR investigation of silicate polymers. Journal of materials science, 44(8) (2009) 2079.

[50] F.A. Miller, C.H. Wilkins, Infrared spectra and characteristic frequencies of inorganic ions. Analytical chemistry, 24(8) (1952) 1253-1294.

[51] V.F. Barbosa, J.K. MacKenzie, C. Thaumaturgo, Synthesis and characterisation of materials based on inorganic polymers of alumina and silica: sodium polysialate polymers. International Journal of Inorganic Materials, 2(4) (2000) 309-317.

[52] H. Aguiar, J. Serra, P. González, B. León, Structural study of sol-gel silicate glasses by IR and Raman spectroscopies. Journal of Non-Crystalline Solids, 355(8) (2009) 475-480.

[53] J. Serra, P. González, S. Liste, C. Serra, S. Chiussi, B. León, M. Pérez-Amor, H.O. Ylänen, M. Hupa, FTIR and XPS studies of bioactive silica based glasses. Journal of Non-Crystalline Solids, 332(1) (2003) 20-27.

[54] R. Gaggiano, I. De Graeve, J.M.C. Mol, K. Verbeken, L.A.I. Kestens, H. Terryn, An infrared spectroscopic study of sodium silicate adsorption on porous anodic alumina. Surface and Interface Analysis, 45(7) (2013) 1098-1104.

[55] E.F. Medvedev, A.S. Komarevskaya, IR spectroscopic study of the phase composition for sodium silicate synthesized in aqueous medium. Glass and Ceramics, 64(1) (2007) 7-11.

[56] D.M. Sanders, W.B. Person, L.L. Hench, Quantitative analysis of glass structure with the use of infrared reflection spectra. Applied Spectroscopy, 28(3) (1974) 247-255.

[57] D.W. Matson, S.K. Sharma, J.A. Philpotts, The structure of high-silica alkali-silicate glasses. A Raman spectroscopic investigation. Journal of non-crystalline solids, 58(2-3) (1983) 323-352.

[58] H. Jansson, D. Bernin, K. Ramser, Silicate species of water glass and insights for alkali-activated green cement. Aip Advances, 5(6) (2015).

[59] I. Halasz, M. Agarwal, R. Li, N. Miller, Vibrational spectra and dissociation of aqueous Na2SiO3 solutions. Catalysis Letters, 117(1-2) (2007) 34-42.

[60] I. Pignatelli, A. Kumar, M. Bauchy, G. Sant, Topological control on silicates' dissolution kinetics. Langmuir, 32(18) (2016) 4434-4439.

[61] R.D. Husung, R.H. Doremus, The infrared transmission spectra of four silicate glasses before and after exposure to water. Journal of Materials Research, 5(10) (1990) 2209-2217.

[62] A. Rafeet, R. Vinai, M. Soutsos, W. Sha, Guidelines for mix proportioning of fly ash/GGBS based alkali activated concretes. Construction and Building Materials, 147 (2017) 130-142. 